\title{
FACTORS CONTROLLING THE RECENT SEDIMENTATION IN THE UPPER CONTINENTAL SLOPE OF THE JACUÍPE BASIN (NE BRAZIL)
}

\author{
Maria Virginia Alves Martins ${ }^{1,2 *}$, Egberto Pereira ${ }^{1}$, Sérgio Bergamaschi ${ }^{1}$, Denise Terroso $^{2}$, Paulo Miranda ${ }^{2}$, \\ Hélio Heringer Villena ${ }^{3}$, Cintia Yamashita ${ }^{4}$, José Carlos Martins Ramalho ${ }^{2}$, Fabrizio Frontalini ${ }^{5}$, Lazaro \\ LAUT $^{6}$ AND FERNANDO ROCHA ${ }^{2}$
}

1 Universidade do Estado do Rio de Janeiro, Av. São Francisco Xavier, 524, Maracanã. CEP 20550-013, Rio de Janeiro, RJ, Brazil.virginia.martins@ua.pt, egberto@uerj.br, sergioberg7@hotmail.com

2 GeoBioTec, Dpto. Geociências, Universidade de Aveiro, Campus de Santiago, 3810-193 Aveiro, Portugal. laraterroso@ua.pt,pfnmiranda@gmail.com,jc_ramalho@hotmail.com, tavares.rocha@ua.pt

3 Faculdade de Oceanografia, Universidade do Estado do Rio de Janeiro, UERJ, Rua São Francisco Xavier, 524, $4^{\circ}$ andar, Bloco E, sala 4018, CEP 20550-900, Rio de Janeiro, RJ, Brazil. heliovillena@gmail.com

4 Universidade de São Paulo, Instituto Oceanográfico, Praça do Oceanográfico, 191, Cidade Universitária. 05508-120 São Paulo, SP, Brazil. cintia.yamashita@usp.br

5 Dipartimento di Scienze Pure e Applicate (DiSPeA), Università degli Studi di Urbino "Carlo Bo", Urbino, Italy. fabrizio.frontalini@uniurb.it

6 Universidade Federal do Estado do Rio de Janeiro (UNIRIO), Laboratório de Micropaleontologia - LABMICRO, Av. Pasteur 458, sala 500, Urca, Rio de Janeiro, RJ, Brazil, CEP 22290-240. lazaro.laut@gmail.com

*Corresponding Author, virginia.martins@ua.pt

Received on 20 Novemvber 2017

Received in revised form on 10 January 2018

Accepted on 25 January 2018

Editor: Maria Antonieta Rodrigues, Universidade do Estado do Rio de Janeiro, Brazil

\section{Abstract}

This work is based on textural, mineralogical (XRD) and compositional data of 50 bottom sediments' samples in the upper continental slope between 80-1000 m water depth of the Jacuípe Basin, northern region of Bahia State (Brazil). It intends to study the recent sedimentary coverture and infer possible conditioning factors influencing the recent sedimentation in this region. Despite the study area has been considered oligotrophic, pyrite that is supposed to be mostly the result of the initial diagenetic processes of organic matter degradation, occurs throughout the upper slope of the Jacuípe Basin. The organic matter flux is abundant enough to establish anoxic environments or microenvironments favorable to the formation and preservation of pyrite. The textural, mineralogical and compositional data allow us to define latitudinal and longitudinal variations of bottom sediments possibly influenced by changes in the
Citation:

Alves Martins, M.V., Pereira, E., Bergamaschi, S., Terroso, D., Miranda, P., Villena, H.H., Yamashita, C., Martins Ramalho, J.C., Frontalini, F., Laut, L., Rocha, F., 2017. Factors controlling the recent sedimentation in the upper continental slope of the Jacuípe Basin (NE Brazil). Journal of Sedimentary Environments, 2 (4): 250-273.

geomorphology of the study area and hydrodynamic conditions. The supply of detrital sediments to the southern region seems to be scarce but relatively more abundant in the northern part, closer to the São Francisco River delta. The northern region is also more favorable to sediment deposition than the southern one, where erosional processes appear to be more common. This difference may also be ascribed to the process of formation of the Brazil Current, and its southward development. A significant compositional change of sediments was observed at about $435 \mathrm{~m}$ depth possibly due to the enhanced influence of the North Brazil Undercurrent.

Keywords: Sediment distribution. Glaucony. Relic/ Palimpsest sediments. Jacuípe Basin. South Atlantic Ocean. North Brazil Undercurrent. 


\section{Introduction}

Sedimentary basins are present on every continent of the planet and the geological record has revealed their existence since the earliest days of Earth's evolution (Martins-Neto, 2006). They correspond to depressions due to land subsidence and receive sediments from the surrounding highlands (Swift and Thorne, 1992). They may take a variety of forms in surface and subsurface and have commonly a thick sedimentary package inside, which tends to decrease in thickness as the edges approach (Burk and Drake, 1974). The sedimentary basins preserve detailed records of the environment and the tectonic processes are important in their establishment (Curray et al., 1977).

A continuous system of sedimentary basins exists in the divergent margin of South America, stretching for more than $12,000 \mathrm{~km}$ from the Orinoco Delta in the Venezuelan East to Tierra del Fuego, in the extreme south of Argentina (Milani et al., 2000). They were originated by lithospheric distension mechanisms during the Mesozoic, that led to the rupture of the paleocontinent Gondwana, and to the definitive separation of the African and South American plates, accompanying the formation of the South Atlantic Ocean (Milani et al., 2000). One of these basins is the Jacuípe Basin where the study area of this work is located (Fig. 1).

\subsection{The main goals}

Few sedimentological works have been performed on the Jacuípe continental shelf, such as those carried out by Netto (2002), Freire (2006), Vieira (2007) and Silva (2008). These authors analyzed the morphology and sedimentology of the continental shelf, but little or nothing was published on the sedimentary deposits of the continental slope of this basin. Thus, this work intends to study the recent sedimentary coverture of the upper slope of Jacuípe Basin (NE Brazilian Continental Margin) and infers on possible factors that influenced the recent sedimentation in the area.

\subsection{Study Area}

The Jacuípe Basin is situated in the maritime portion of the northern coast of the Bahia State (Fig. 1), between the city of Salvador and the border of the Bahia and Sergipe states (NE Brazil). The Jacuípe Basin stretches for about 210 $\mathrm{km}$ in SW-NE direction and has an average width of $35 \mathrm{~km}$ at the 2000-m bathymetry (Mohriak, 2003). It extends over an area of approximately $7,500 \mathrm{~km}^{2}$, from which about 4,500 $\mathrm{km}^{2}$ are within 400-m water depth (Mohriak, 2003). This basin is limited to the north by the Sergipe-Alagoas Basin, through the Vaza-Barris fault, and to the south by the Camamu Basin, through the Itapuã transfer zone (Netto et al., 1994). On the mainland, it is separated from the Recôncavo Basin by the Barra fault (Netto et al., 1994). The beginning of its development and structuring extended from the Hauterivian to Aptian (Freitas and Ferreira, 2015). The basin was formed in the region where the "Paleo Alto de Jacuípe" was located, a structural high located between the Recôncavo and Gabon basins (Wanderley Filho and Graddi, 1995).

According to Mohriak (2003), the current known stratigraphic framework of the Jacuípe Basin includes two megasequences, corresponding to the syn-rift (continental) and post-rift (marine) phases. The syn-rift phase, poorly developed in the continental shelf, encompasses the Rio de Contas Formation (lower Cretaceous) that is composed of sandstones, conglomerates and shales. The post-rift phase includes the transgressive marine sequence, predominantly carbonate, of Albian-Turonian age (Algodões Formation), and predominantly clayey from the Urucutuca (upper Cretaceous) Formation (Fm).The regressive marine sequence, characterized by a prograding sequence, is represented by the proximal and littoral sandy facies of the Rio Doce Fm, the carbonate platform of the Caravelas Fm and slope shales of the Urucutuca (Tertiary-Quaternary) Fm.

Two main areas can be recognized in the Jacuípe Basin. The first one is defined by the Jacuípe continental shelf, which extends from the coastline until the shelf break, with average depths of $70 \mathrm{~m}$ and where shallow grabens occur. The second domain starts at the main edge fault with $\mathrm{N} / \mathrm{NE}$ direction, which coincides with the current continental shelf break, where the sedimentary package can be 7,000 $\mathrm{m}$ thick (Mohriak et al., 1998).

The continental margin, in the northern portion of Bahia (north of Salvador), is characterized by a system of poorly developed sea terraces on the coastal plain, and by the narrow continental shelf, with an average width of $20 \mathrm{~km}$ and a minimum of $8 \mathrm{~km}$ off Salvador city. The slope has an average width between 80 and $100 \mathrm{~km}$, with a declivity between 1 and $28^{\circ}$, with a strong slope in the upper part of the slope up to 400-800 m depth (Leão and Brichta, 1996).

The coastal plain of the study area consists of rocks of the Pre-Cambrian and Mesozoic basement (São Sebastião Fm) and accumulated sediments of the Tertiary (Barreiras Fm) and the Quaternary (Dominguez et al., 1996). In the inner and middle part of the continental shelf, there are lines of internal and external strands of beach rocks, as well as coral reef constructions and coralline algae, which are related to transgressive events that occurred during the Quaternary (Martin et al., 1985; Dominguez et al., 1996). 


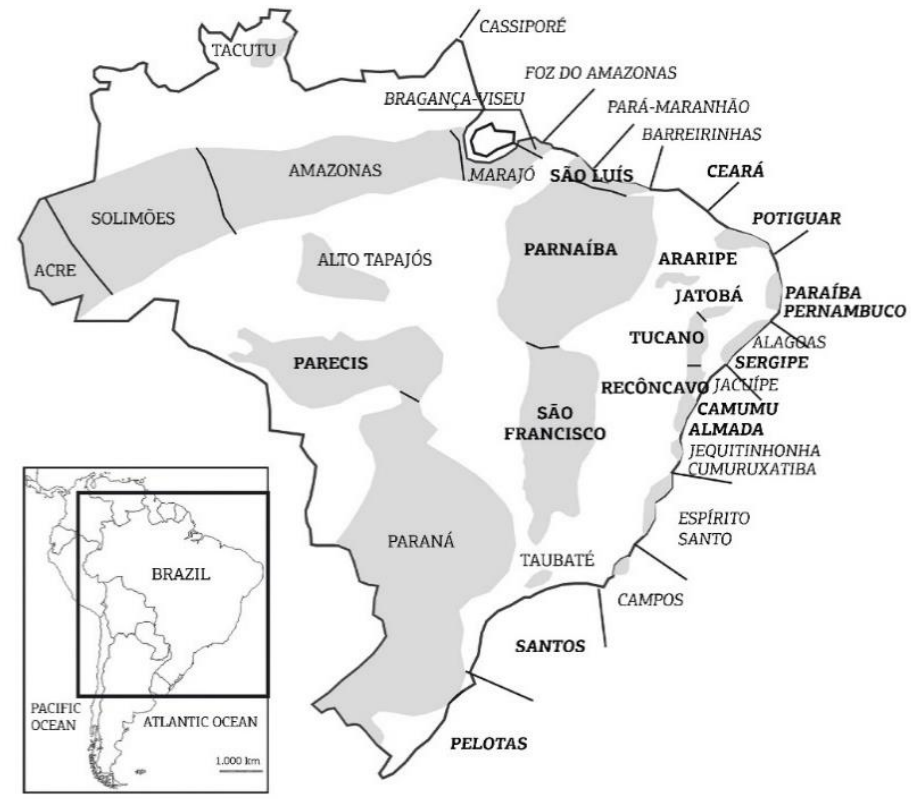

A

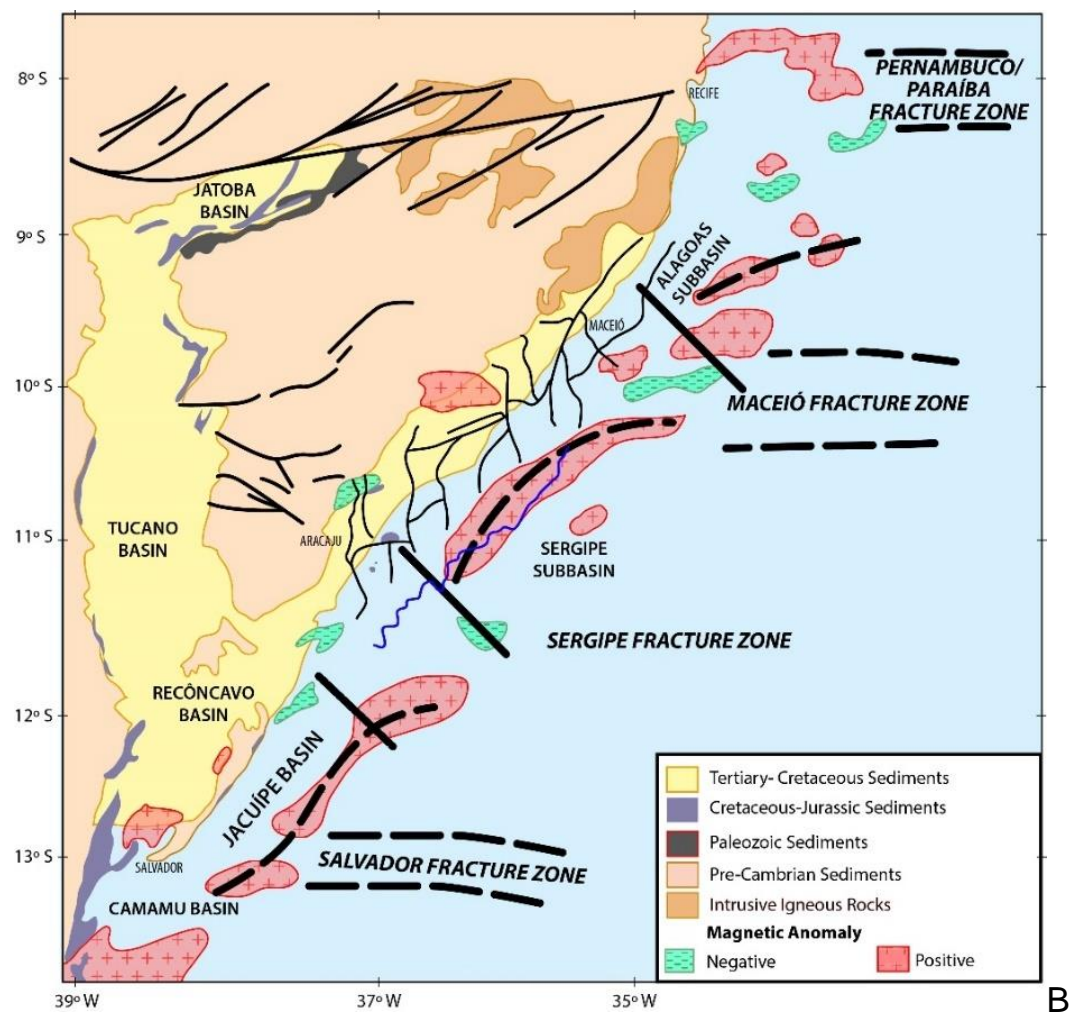

Fig. 1. A. Brazilian sedimentary basins (modified from Milani et al., 2007). B. Location of the Jacuípe Basin (modified from Mohriak, 2003). 
The surface bottom sediments at the continental shelf along the entire Bahia State constitute two sedimentary facies: terrace facies, composed of siliciclastic sediments of continental origin, on the inner continental shelf, and carbonaceous facies, composed of sediments of biogenic origin in the mid and outer shelf (Melo et al., 1975; Summerhayes et al., 1975; Araújo, 2004). Muddy sediments are accumulated in lower energy zones, in areas deeper than 35 m (Dominguez et al., 1996; Araújo, 2004).

Two currents are present in the Jacuípe Basin: Brazil Current (BC) and North Brazil Undercurrent (NBUC). The $\mathrm{BC}$ originates north of $10^{\circ} \mathrm{S}$ and starts flowing with a vertical extension of less than $100 \mathrm{~m}$ deep with maximum speed of $0.25 \mathrm{~m} \mathrm{~s}^{-1}$. The BC is a weak and shallow current at about $10^{\circ} \mathrm{S}$. Between $10^{\circ} \mathrm{S}$ to $13^{\circ} \mathrm{S}$, it was observed in the austral summer only the presence of the NBUC (from the surface up to $1000 \mathrm{~m}$ deep). At $14.5^{\circ} \mathrm{S}$, the $\mathrm{BC}$ is attached to the continental margin (Silveira et al., 2000). The NBUC originates at about $20^{\circ} \mathrm{S}$ with a velocity core centered at 700 $\mathrm{m}$ (Soutelino, 2008; Soutelino et al., 2011). As flowing northward, this undercurrent increases transport and its velocity core becomes shallower. The core reaches the depth of $250 \mathrm{~m}$ with maximum speed of $0.58 \mathrm{~m} \mathrm{~s}^{-1}$ in the study area (Soutelino, 2008; Soutelino et al., 2011).

Near the origin area, the BC transports southward the Tropical Water (TW) (Fig. 2). The Intermediate Western Boundary Current (IWBC) flows opposing to the BC direction that transports the Antarctic Intermediate Water (AAIW) at North of $28^{\circ} \mathrm{S}$. Therefore, the SACW flows north at North of $21^{\circ} \mathrm{S}$, adding transport to the IWBC and starting a flow that is the North Brazil Undercurrent (NBUC). The NBUC vertical extension is of about $1200 \mathrm{~m}$ (Soutelino et al., 2013).

The continental shelf of the Jacuípe Basin is governed by a mesotidal regime (Ekau and Knoppers, 1999; Marone et al., 2010). On the continental shelf, the currents normally follow according to the prevailing winds direction: predominantly to SW in the summer and towards NE in winter (Dominguez et al., 2003). The effective coastal sediment drift in the study area has SW-NE direction (Livramento, 2008).

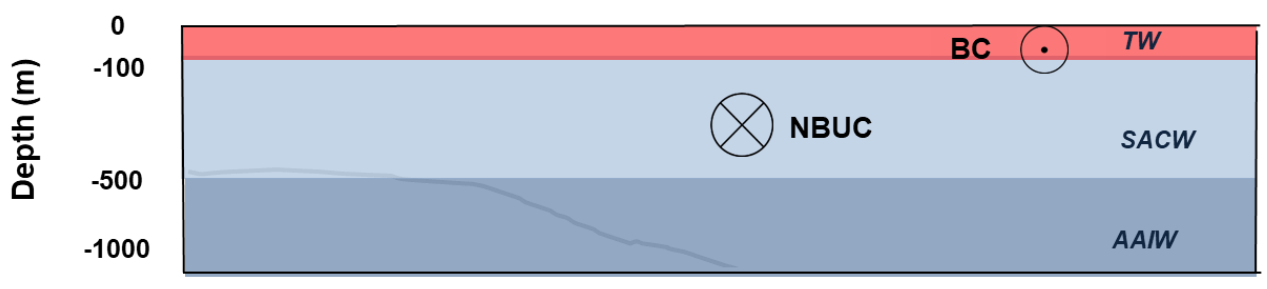

Fig. 2. Schematic water mass stratification and the currents in the study area: Tropical Water (TW); South Atlantic Central Water (SACW); Antarctic Intermediate Water (AAIW); Brazil Current (BC); and North Brazil Undercurrent (NBUC). Symbols inside the circles indicate the flow direction, $\mathrm{X}$ to the north and dot to the south (Based on Soutelino, 2008).

\section{Material and methods}

\subsection{Sampling and laboratorial analyses}

This work is based on the analysis of 50 Piston Core sediment samples collected by the Agência Nacional do Petróleo $e$ Biocombustiveis (ANP, Brazil) in the upper continental slope (between 80-1000 $\mathrm{m}$ depth) of the Jacuípe Basin (northern region of the Bahia State, Brazil) between May and September 2009.

This work makes part of a wider study that intends to map the recent sedimentary facies of the Jacuípe Basin. Samples location and depth in the Jacuípe Basin is presented in Appendix 1 and Figure 3. Brazilian polyconic coordinates in the samples' location are used (Appendices 1 and 2). The analyzed subsurface $(1-5 \mathrm{~cm})$ samples were preserved frozen until to be submitted to textural, mineralogical and compositional analyses. For these analyses, sediments were dried in an oven at less than $60^{\circ} \mathrm{C}$.

Sediment grain size was determined by classic sieving techniques. After drying the sediment, a split of each sample was weighed. Sand and fine fractions were separated by wet sieving with distilled water, using a $63 \mu \mathrm{m}$ mesh sieve. Both sedimentary fractions were collected in containers, dried in an oven at less than $60^{\circ} \mathrm{C}$ and weighed. The sediment fraction $>63 \mu \mathrm{m}$ was separated into several granulometric fractions of the following dimensions: $63 \mu \mathrm{m}, 125 \mu \mathrm{m}, 250 \mu \mathrm{m}, 500 \mu \mathrm{m}$, $1000 \mu \mathrm{m}, 2000 \mu \mathrm{m}$ and $4000 \mu \mathrm{m}$. Numerical grain-size parameters allow to detect important properties related to grain size, such as sediment mean grain size (SMGS), sorting, skewness and kurtosis. These textural parameters as well as the textural group and samples description were done according to Folk and Ward (1957), using the GRADISTAT v.8 software.

The mineralogical composition was analyzed by X-Ray Diffraction (XRD) techniques in sediment fine fraction $(<63$ $\mu \mathrm{m})$, at the X-Ray Diffraction and Geochemical Laboratory, of the Geosciences Department, of Universidade de Aveiro (Portugal). The methodologies described by Martins et al. (2007) were applied for the minerals identification and semiquantification of the mineralogical composition of the sediments. 


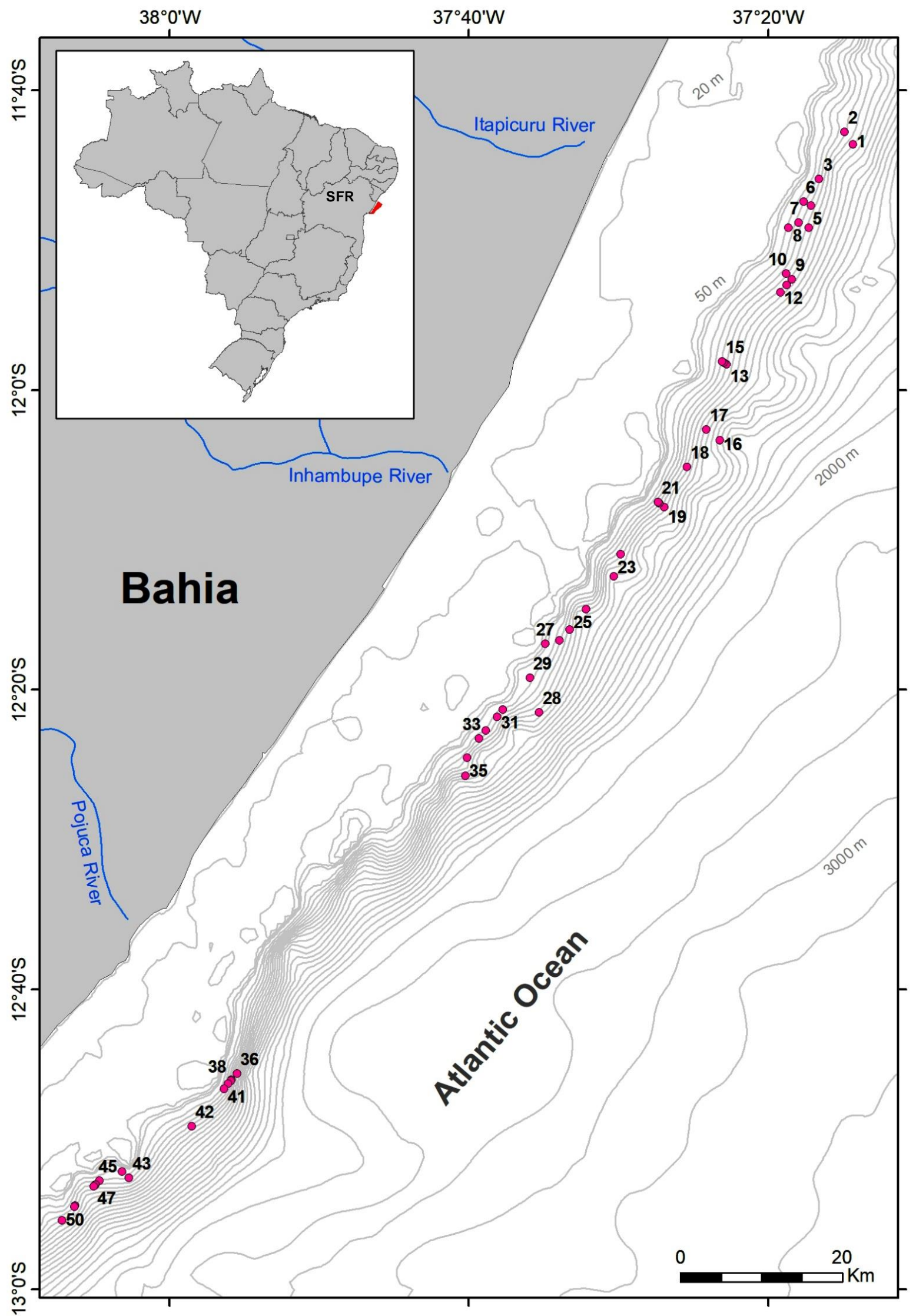

Fig. 3. Samples location in Jacuípe Basin. Legend: SFR - São Francisco River. 
The compositional analysis was carried out by counting and identifying grains on the sediment fraction $250-500 \mu \mathrm{m}$. This sediment fraction was chosen for easing the identification and counting of sedimentary grains and because it is present in all samples. More than 300 sedimentary particles were identified and counted in each sample. The percentage of identified sedimentary particles was calculated.

\subsection{Statistical analysis}

Selected variables were transformed by $\log (x+1)$ before statistical analyses. Cluster analyses (CA) and Principal Component Analysis (PCA) and correlations between the variables were carried out with Statistica 12 software. QMode and R-mode CA, based on Complete Linkage and 1 Pearson r, were used to discriminate groups of variables and stations where selected data present similar patterns of distribution.

Variables obtained by XRD-mineralogical analysis (in fine fraction; $<63 \mu \mathrm{m}$ ) were signed with an asterisk $\left(^{*}\right)$ and grains of coarse sediment fraction (CSF; 250-500 $\mu \mathrm{m}$ ) with .G, whenever it is necessary to differentiate the components of these two sedimentary fractions. The maps were performed with the ArcGIS 10.2 software.

\section{Results}

\subsection{Sediments texture}

The SMGS is one of the statistical parameters that best represents the sedimentary particles population center (Davis, 1986) and ranges in the studied samples (Fig. 4A) between $16 \mu \mathrm{m}$ and $1399 \mu \mathrm{m}$ (mean: $131 \mu \mathrm{m}$ ). Considering the values of SMGS, sediments range from coarse silt to very coarse sand (Appendix 1). The percentage of gravel (050.1\%; mean: 4.1\%), sand (1.5-97.2\%; mean: $4.1 \%$ ) and fine fractions $(2.8-98.5 \%$; mean: $53.7 \%)$ vary significantly in the studied sites. The substrates in most of the sites (29) are composed of sandy sediments. However, muddy sediments are found in a significant number of sites (21).

Most of the sites (27) have very poorly sorted and extremely poorly sorted (22) sediments (Appendix 1). Grain size distribution changes between very fine skewed to coarse and very coarse skewed (Appendix 1). The degree of flatness of the graphic representation in relation to the normal distribution is, in most of the sites, platykurtic and mesokurtic. In most stations, the substrate has polymodal and trimodal populations of particles being the most frequent modes 1, 2 and 3, centered at $77 \mu \mathrm{m}, 153 \mu \mathrm{m}$ and $303 \mu \mathrm{m}$.

\subsection{Mineralogical composition of fine fraction $(<63 \mu \mathrm{m})$}

The mineralogical composition of fine fraction (Appendix 1) is mostly represented by phyllosilicates
(<69.0\%; mean, 35.3\%), quartz (1.1-45.6\%; mean, $14.8 \%)$, calcite (1.3-42.6\%; mean, 14.7\%), plagioclase $(<17.3 \%$; mean, 3.6\%), K-feldspar (<22.9\%; mean, 5.5\%), basanite (< $3.5 \%$; mean, $5.5 \%)$, dolomite $(<12.2 \%$; mean, $1.7 \%)$, siderite $(<12.0 \%$; mean, $2.8 \%)$ and pyrite $(<10.0 \%$; mean, $4.4 \%$; Fig. 4B). Other identified minerals are gypsum $(<8.5 \%$; mean, $3.7 \%)$, aragonite $(<8.7 \%$; mean, $1.3 \%)$, anatase $(<9.3 \%$; mean, $3.7 \%)$, anhydrite $(<7.1 \%$; mean, $0.8 \%)$ and strontianite (6.2\%; mean, $2.1 \%)$.

Percentage of total detrital minerals (27.1-94.1\%; mean, $63.0 \%$ including phyllosilicates, quartz, K-feldspar, plagioclase and anatase are the main minerals $(>50 \%$; Fig. 4C) constituting the fine fraction in most of the sites (Fig. 5A). The ratio K-feldspar/Quartz has significant variability in the study area /Appendix 1). The values of $\mathrm{K}$ Feldspar/Quartz* ratio $(<8.8 \%$; mean, $0.7 \%)$ reach percentages $\geq 1 \%$ in 26 sites (Fig. $4 \mathrm{D}$ ).

The percentage of carbonates (aragonite, calcite, dolomite, siderite and strontianite) reaches relatively high values in the study area (4.7-45.4\%; mean, $22.6 \%$ ).

Sulfates (anhydrite basanite and gypsum) are generally a minor component of sediments $(<22.5 \%$; mean, $10.0 \%)$.

\subsection{Composition of coarse sediment fraction}

The percentage of identified particles in the CSF is presented in Appendix 2. As the sedimentary particles are covered by a chemical precipitate, it was not possible to analyze the CSF composition at sites 8, 20, 21 and 48. The CSF is composed of Total Detrital.G minerals (Fig. 4E; such as Quartz.G, Feldspars.G, Mica.G, Sedimentary Aggregates.G and Other Minerals.G), authigenic/diagenetic particles (such as Glaucony.G, Pyrite.G, Pyritized Foraminifera.G, NonBiogenic Carbonates.G), Biogenic Particles.G, including Undetermined Bioclasts.G, Well and Poorly Preserved Benthic and Planktonic Foraminifera, and other biogenic particles (such as Mollusk Shells, Ostracod Valves, Bryozoan Fragments, Sponge Spicules, Sea Urchin Spicules and Pteropod Fragments).

Contrasting with the composition of fine fraction (containing mostly detrital minerals), the main component of the CSF in most sites are carbonates and, within these, biogenic particles are those that reach the highest percentages (Fig. $5 \mathrm{~B}$ and Appendix 1).

The detrital component of CFS consists mainly of quartz and feldspars; mica is quite rare (Appendix 1) and reaches relatively high values in some stations mainly in the center and northern regions of the study area (Fig. 5 B).

The proportions of biogenic particles, glaucony, pyrite and non-biogenic carbonates vary considerably (Fig. 5 B). Pyrite, and glaucony particles reach relatively high percentages at some sites. Biogenic carbonated particles dominate in most of the sites in CFS. 


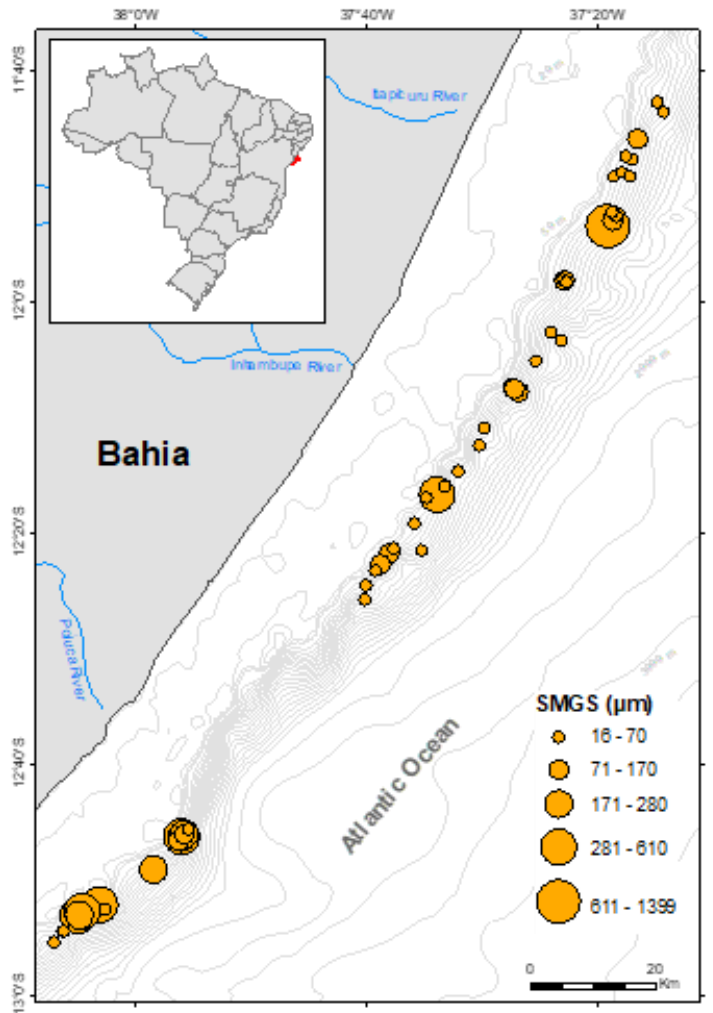

A)
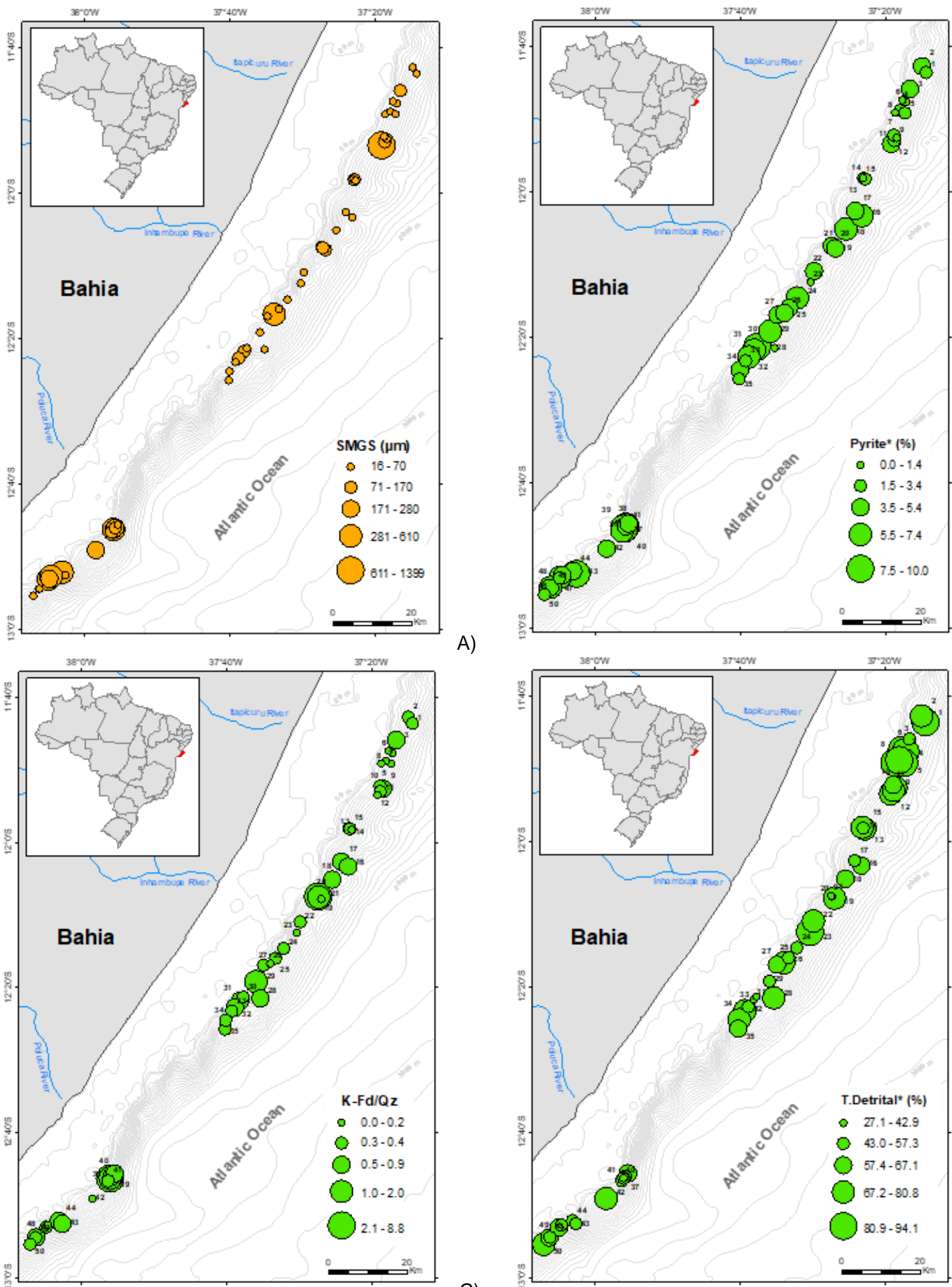

B)

C)

Fig. 4. Maps of distribution of A) Sediment Mean Grain Size - SMGS ( $\mu \mathrm{m}$ ) and of some mineralogical data of fine fraction; B) Pyrite* (\%); C) K-Fd/Qz - K-Feldspar/Quartz* ratio and; D) Total Detrital* minerals (\%). 


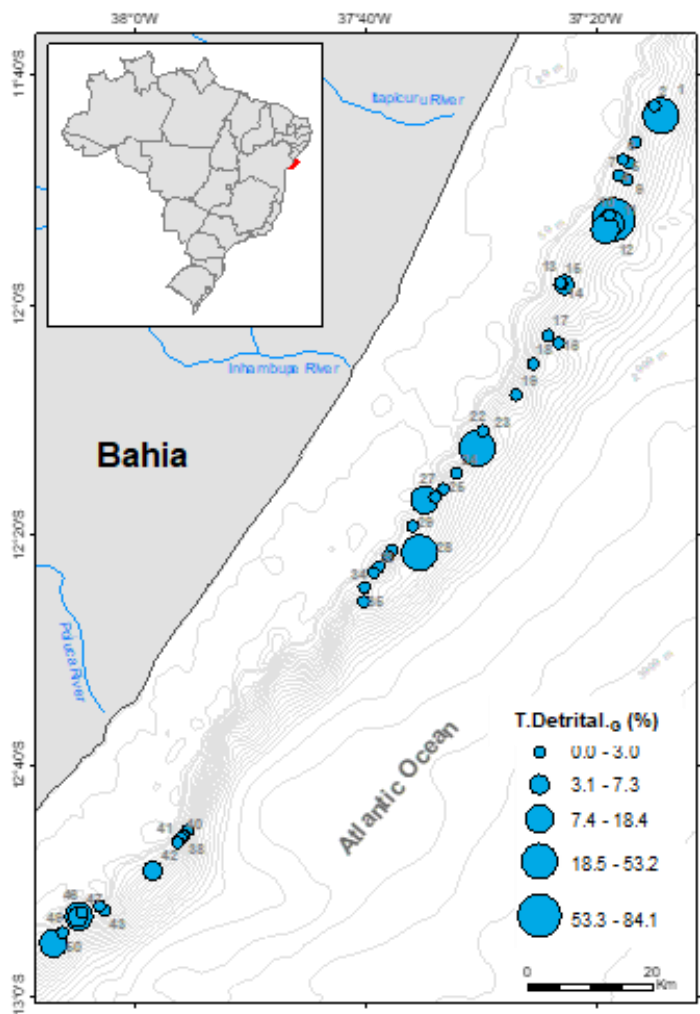

E)

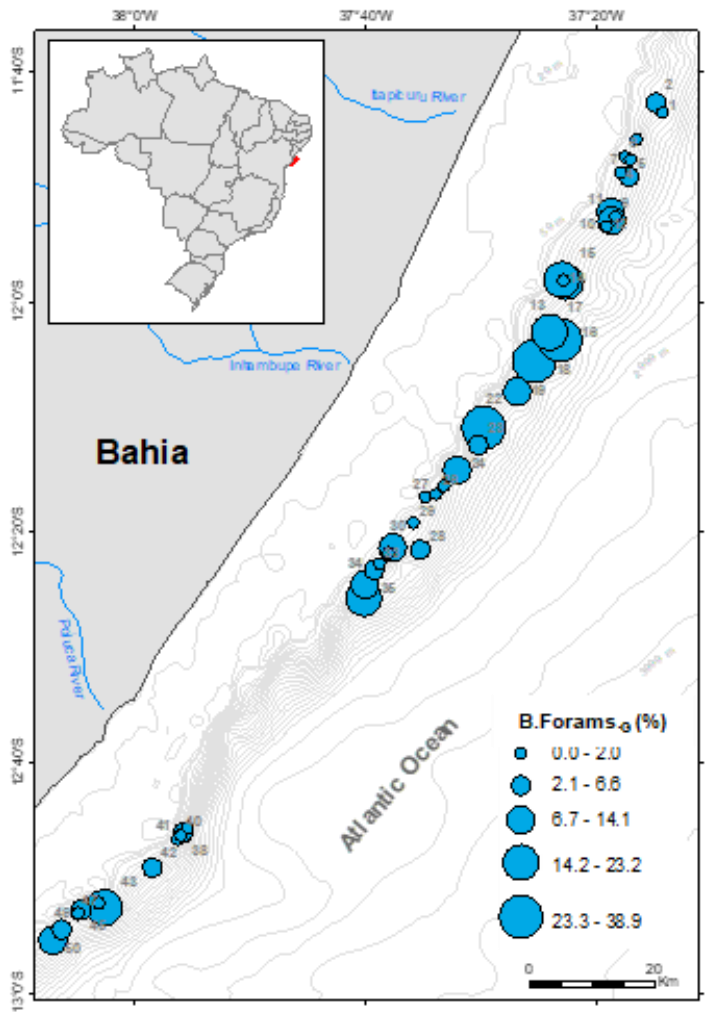

F)

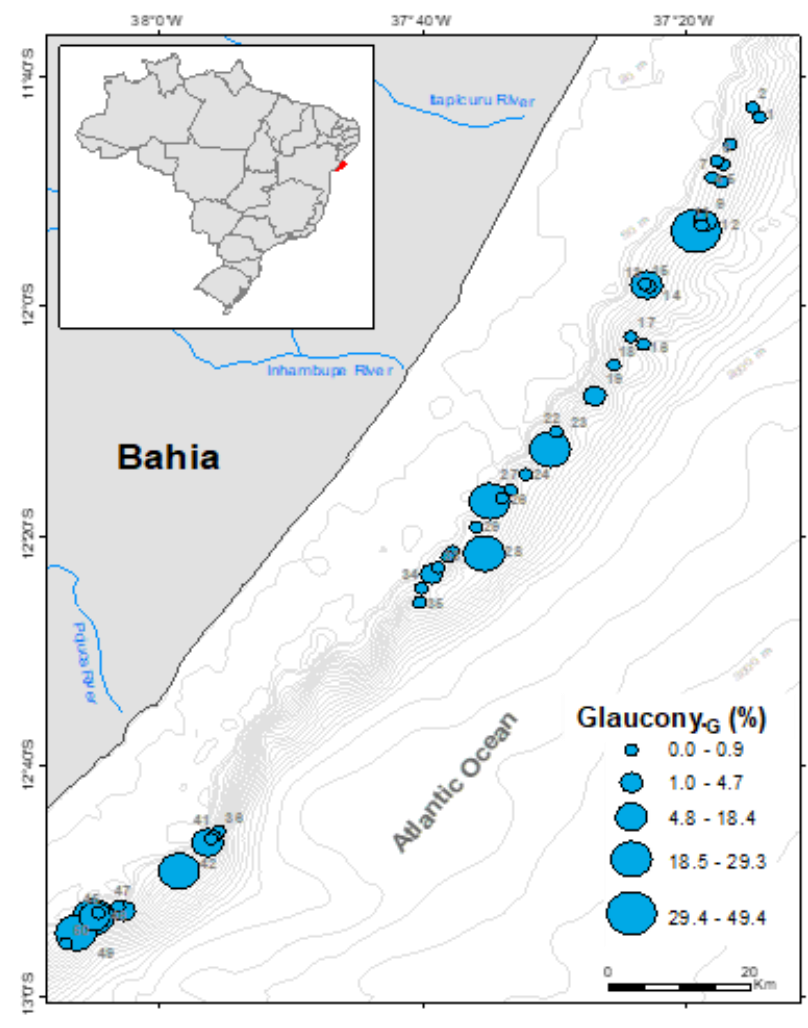

G)

Fig. 4. (cont.) Maps of distribution of some variables of coarse sediment fraction (CSF; 250-500 $\mu \mathrm{m}$ ) are also presented: E) T.Detrital.G - Total Detrital.G minerals F); B.Foram.G - Well Preserved Benthic Foraminifera (\%); G) Glaucony.G (\%). 


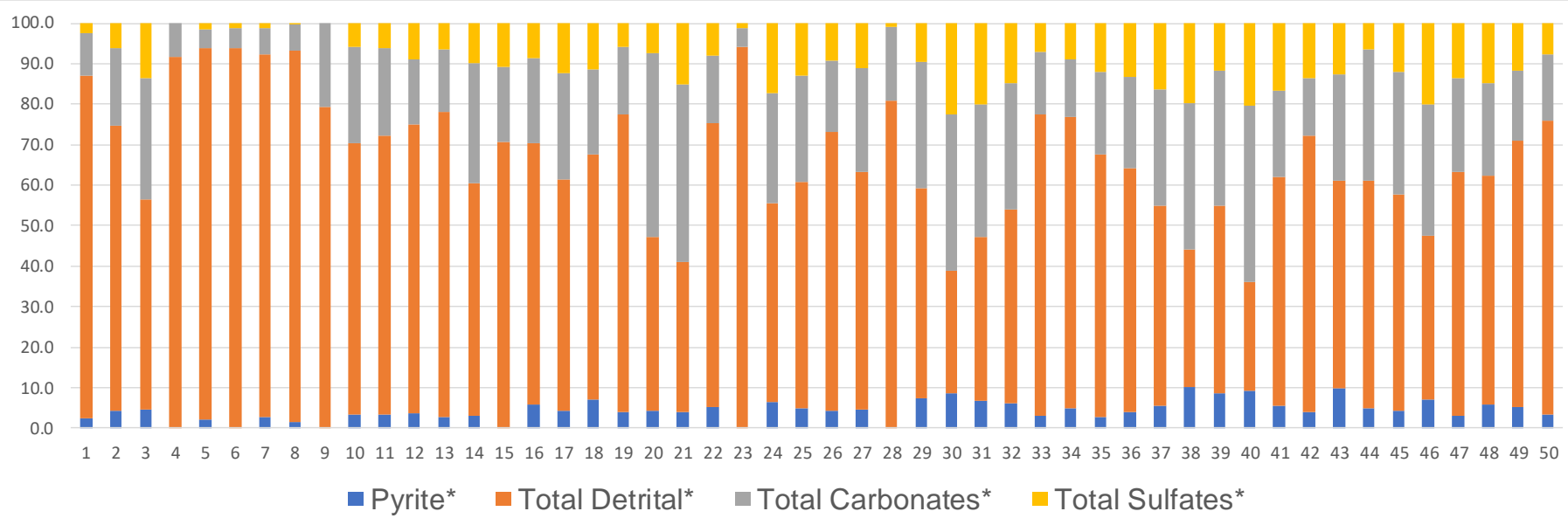

A.

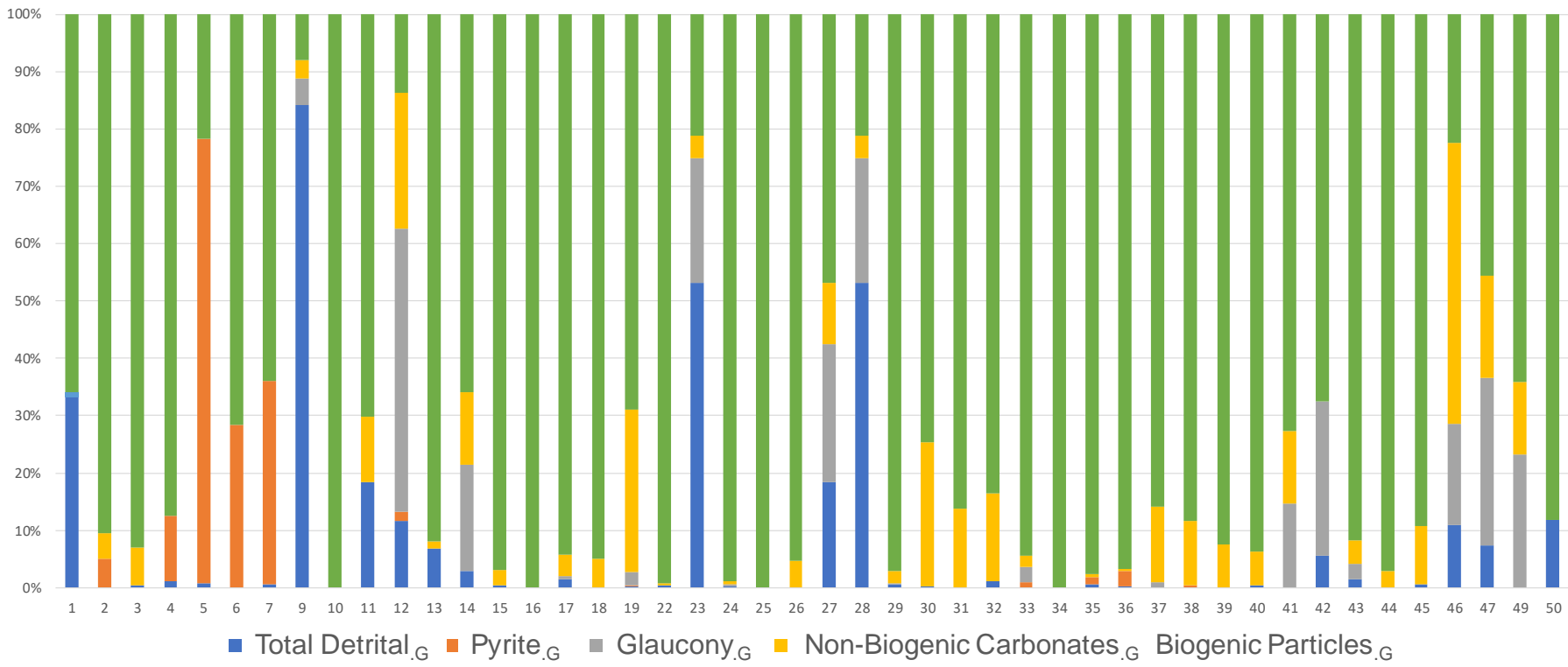

B.

Fig. 5. A. The main minerals of sedimentary fine fraction $(*)$ : Pyrite *; Total Detrital* minerals (including anatase, K-feldspar, phyllosilicates, plagioclase and quartz); Total Carbonates* minerals (aragonite, calcite, dolomite, siderite and strontianite); Total Sulfates* minerals (anhydrite and basanite). B. Percentage of grains in CSF (.G): Total Detrital.G minerals (including quartz, feldspars, mica and other minerals); Pyrite.G; Glaucony.G; Non-Biogenic Carbonates.G and Biogenic Particles.G (including undetermined bioclasts, well and poorly preserved benthic and planktonic foraminifera, fossils of foraminifera and other biogenic particles, such as mollusk shells, ostracod valves, bryozoan fragments, sponge spicules, sea urchin spicules and pteropod fragments).

\subsection{Correlations between variables}

The correlations between the analyzed variables are presented in Appendix 3. From these values we can mention, for example, that: SMGS has significant positive correlations with Gravel Fraction (Fig. 6), Sorting, Kurtosis, Sand Fraction, Anhydrite*, Aragonite*, Basanite*, Pyrite*, Strontianite*, Total Carbonates*, Total Sulfates*, Glaucony.G and Non-Biogenic Carbonates.g and negative ones with
Depth, Skewness, Fine Fraction, Phyllosilicates*, Total Detrital* minerals, Well Preserved Benthic Foraminifera.G, Well Preserved Planktonic Foraminifera.G, Mollusk Shells.G., Ostracod Valves.g and Pteropod Fragments.G.

Depth has significant positive correlations for instance with: Fine Fraction, Siderite*, Total Detrital* minerals, namely Quartz* and Quartz.G and negative one with Total Carbonates*, namely Aragonite* (Fig. 7 A); Total Detrital* 
minerals are negatively correlated with Total Carbonates* and Total Sulfates* and Basanite* (Fig. 7 A, B, C, D). Basanite* is for instance positively correlated with Gypsum*, Strontianite* and Pyrite* (Fig. 7 E, F, G), as well as Calcite* and Pyrite* (Fig. $7 \mathrm{H}$ ).

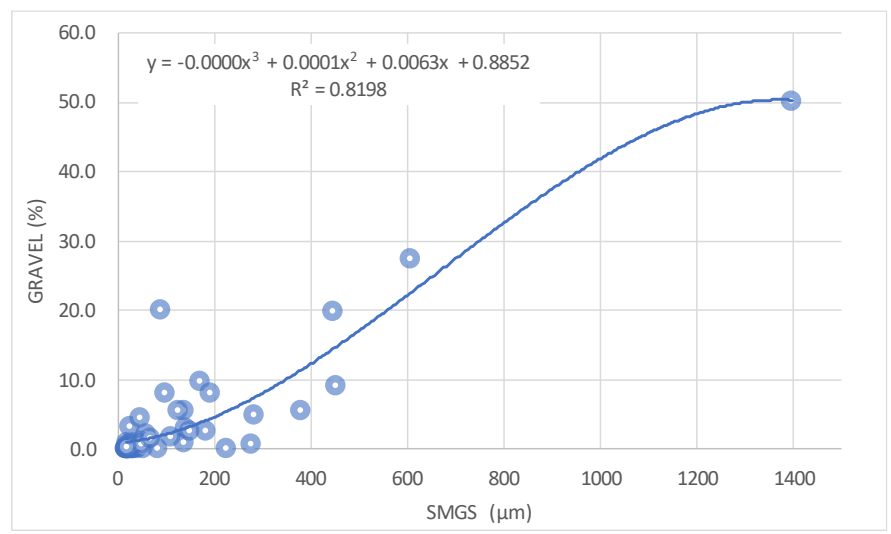

Fig. 6. Scatter diagram of gravel fraction content (\%) against sediment mean grain size (SMGS; $\mu \mathrm{m}$ ). The trend line, equation and $\mathrm{R}^{2}$ value are presented.

\subsection{Cluster Analysis}

The R-mode Cluster Analysis (CA) was performed to group variables with similar pattern of distribution. In the dendrogram presented in Figure 8, two main clusters and two sub-clusters can be identified. This analysis shows that the variables of Group 1 are associated with finer grained sediments and depth whereas the variables of Group 2 tend to occur in coarse grained sediments.

The Q-Mode CA, based on selected textural data (SMGS, Sand Fraction, Fine Fraction), XRD-mineralogical data (percentage of Aragonite*, Basanite*, Calcite*, Phyllosilicates*, Pyrite*, Strontianite*, Total Detrital* minerals), compositional variables of CSF (250-500 $\mu \mathrm{m}$;

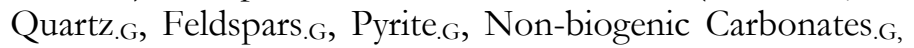
Well Preserved Benthic Foraminifera.G, Well Preserved Planktonic Foraminifera.G, Ostracod Valves.G, Pteropod Fragments.G, Total Detrital*, Total Biogenic*, Total Carbonates*) and Depth. The Q-mode CA allows us to identify two main clusters and five sub-clusters of sites (Fig. 9).

Table 1 presents the mean values of each variable used in the Q-mode CA to highlight differences between clusters and sub-clusters, also including the mean values of other variables such as Mode 1 (textural statistical variable), Gravel content, Pyritized Foraminifera, K-Feldspar/Quartz* ratio, Total Carbonates*, Total Sulfates*, K-Feldspar* and Anhydrite*, which also help to clarify differences in the clusters and subclusters of sites. These data allow us to observe that sites of Cluster 1 are in general situated in shallower water locations and have highest SMGS, Mode 1 values, Sand and Gravel fractions contents whereas sites of Cluster 2 are, in general, related to fine grained sediments (highest proportions of fine fraction) and are situated at deeper locations. Sites of Cluster 1 are also characterized by relatively high percentages of other variables, such as Anhydrite*, Aragonite*, Basanite*, Calcite*, K-Feldspar*, Pyrite*, Strontianite*, Total Carbonates*, Total Sulfates*, K-Feldspar/Quartz* and NonBiogenic Carbonates.g. The mentioned variables reach higher values in Sub-Cluster 1.1 than in Sub-Cluster 1.2. On the other hand, relatively high percentages of Phyllosilicates* and Total Detrital* minerals are observed in general in the sites included in Cluster 2.

The relationships between Glaucony.g and selected variables based on their significant correlations, in 18 sites with this mineral, were assessed by PCA. The PCA plot of the first two factors, which explain most data variably $(68 \%)$, is presented in Figure 10. The PCA results show that: KFeldspar/Quartz*, Calcite*, Total Biogenic. G, Well Preserved Planktonic and Benthic Foraminifera and Poorly Preserved Planktonic Foraminifera and Ostracod Valves are negatively correlated with Factor 1 whereas; Glaucony.G, SMGS, Gravel, Very Coarse Sand, Coarse Sand, Siderite*, Total detrital.G minerals and Quartz.G are positively correlated with Factor 1.

The set of variables in 18 sites, used in the PCA of Figure 10, were also submitted to Q-Mode CA. The results of this CA are presented in Figure 11. This analysis groups the stations in two main clusters and four sub-clusters. The mean values of the variables for each sub-cluster were determined (Appendix 4) and used in sediments provenance interpretation (next section). In addition, the mapping of the sites belonging to each sub-cluster of Q-Mode CA of Figure 9 was also performed to highlight changes in the sedimentary processes (Fig. 12).

\section{Discussion}

\subsection{General characteristics of the sediments in the study area}

The sediments are composed by three main sedimentary fractions: fine, sand and gravel fractions. Gravel is the least abundant sediment fraction but reaches relatively higher percentages at some sites $(11,12,20,21,39,42,44$ and 47). The greater presence of gravely particles induces higher values of kurtosis (Appendix 3). In most of the sites, trimodal and polymodal particles are found that imply a substrate resulted from the combination of several sediment loads deposited by currents and oceanographic processes with different characteristics.

Most of the sites show proportions of fine fraction ranging from 55-98\%. Only five sites display percentages of fine fraction $<10 \%$. 


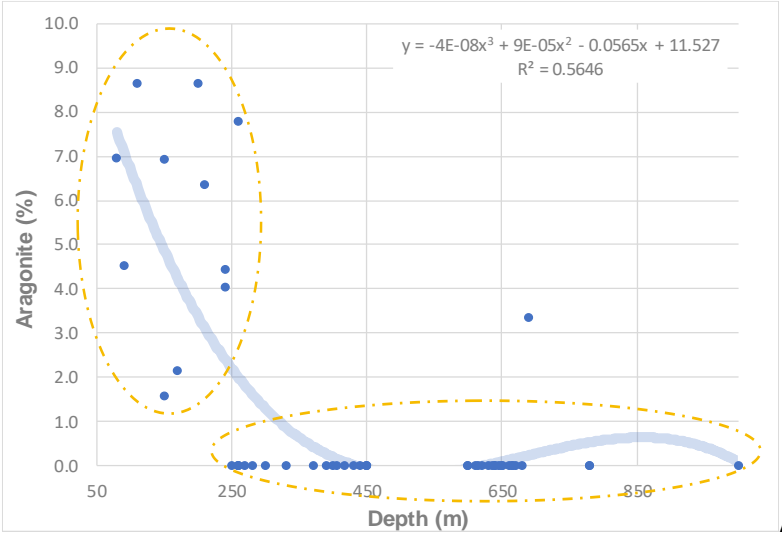

A
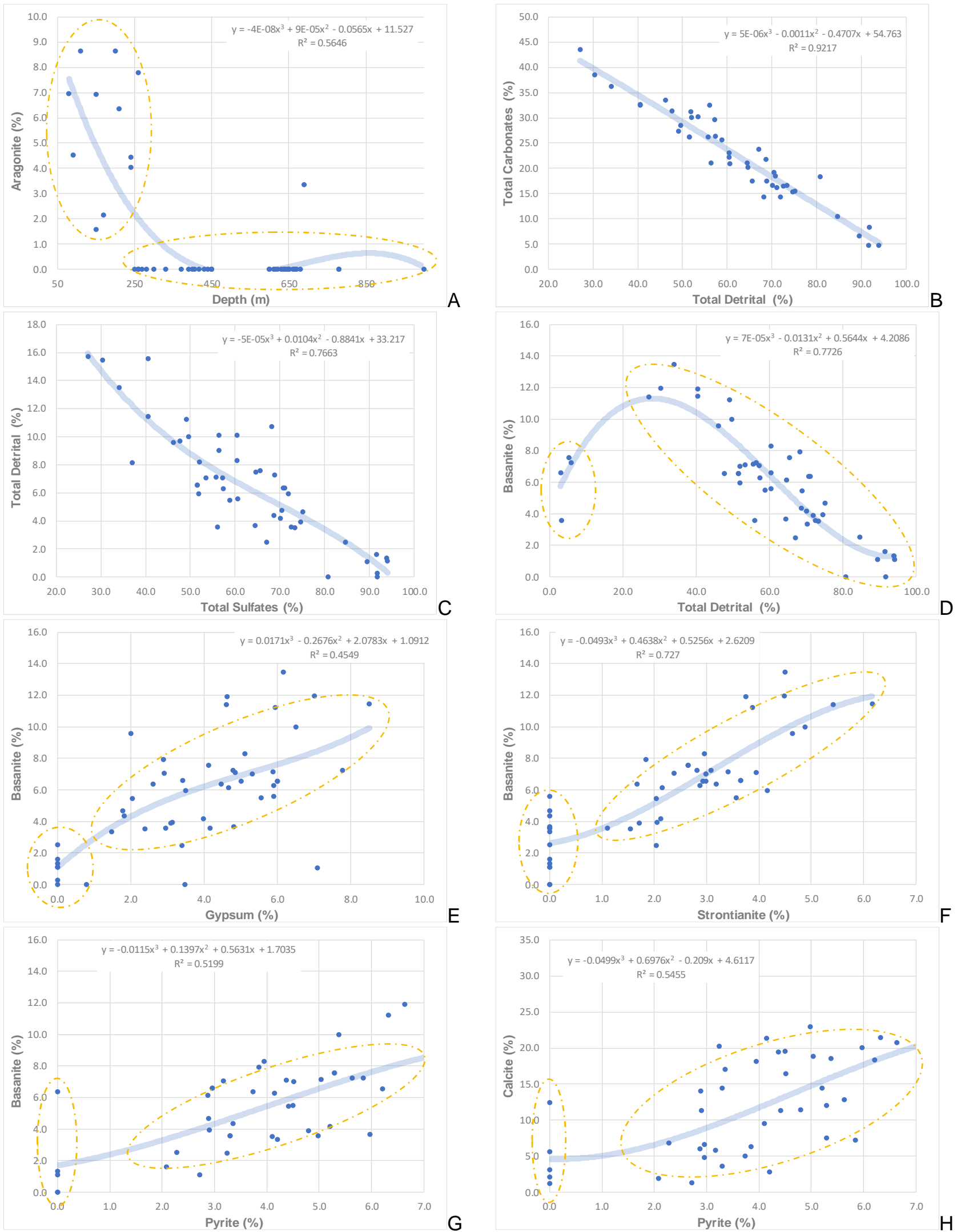

$E$

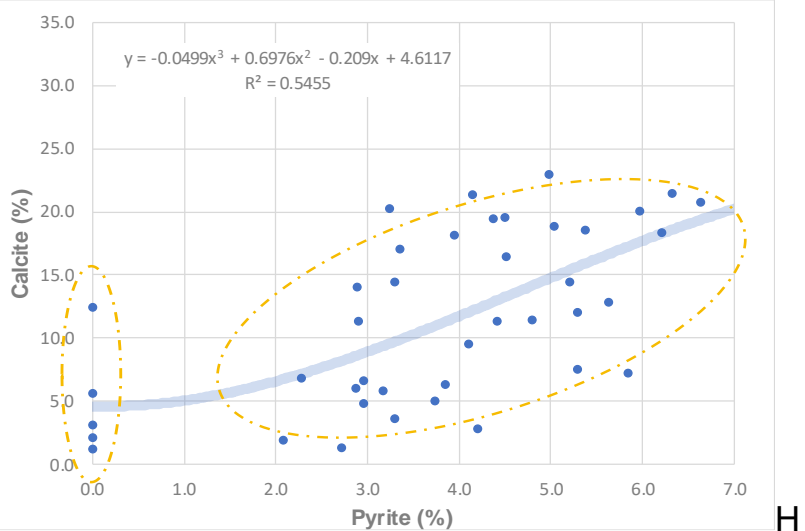

Fig. 7. Scatter diagrams based on the percentage of selected minerals and groups of minerals that compose the fine fraction of the sediments: a) Aragonite (\%) x Depth (m); b) Total carbonates x Total detrital; c) Total detrital x Total sulfates; d) Basanite x Total detrital; e) Basanite x Giypsum; f) Basanite x Strontianite; g) Basanite x Pyrite and; h) Calcite x Pyrite. The trend line, respective equation and R ${ }^{2}$ value are presented in each diagram. 
Tab. 1. Mean values of the variables that compose the Clusters and Sub-Clusters (organized from the smallest to the greatest mean depth) identified by Q-Mode CA (Fig. 9). The highest values are shaded.

\begin{tabular}{|c|c|c|c|c|c|}
\hline \multirow{2}{*}{ Variables / Clusters and Sub-Clusters } & \multicolumn{2}{|c|}{ Cluster 1} & \multicolumn{3}{|c|}{ Cluster 2} \\
\hline & 1.1 & 1.2 & 2.3 & 2.2 & 2.1 \\
\hline Depth (m) & 220 & 435 & 436 & 647 & 657 \\
\hline SMGS $(\mu \mathrm{m})$ & 361 & 114 & 20 & 23 & 23 \\
\hline Mode 1 & 577 & 434 & 77 & 114 & 177 \\
\hline Gravel Fraction (\%) & 10.3 & 4.3 & 0.2 & 0.1 & 1.5 \\
\hline Sand Fraction (\%) & 76.0 & 53.1 & 12.3 & 18.0 & 20.2 \\
\hline Fine Fraction (\%) & 13.7 & 42.6 & 87.5 & 81.9 & 78.3 \\
\hline Anhydrite* $(\%)^{\prime}$ & 1.3 & 0.8 & 0.3 & 0.2 & 0.0 \\
\hline 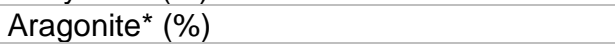 & 4.5 & 0.7 & 0.0 & 0.2 & 0.0 \\
\hline Basanite* $(\%)^{\prime}$ & 8.4 & 7.2 & 1.5 & 5.1 & 2.6 \\
\hline Calcite* (\%) & 18.9 & 14.6 & 2.8 & 15.0 & 7.5 \\
\hline K-Feldspar* (\%) & 5.1 & 5.6 & 4.1 & 4.2 & 4.8 \\
\hline Phyllosilicates* $(\%)$ & 26.3 & 28.4 & 54.2 & 42.3 & 42.6 \\
\hline 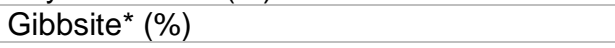 & 4.7 & 4.3 & 0.3 & 4.1 & 2.3 \\
\hline Pyrite* $\left.^{*} \%\right)$ & 6.3 & 4.8 & 1.8 & 4.3 & 3.2 \\
\hline Strontianite $^{*}(\%)$ & 3.7 & 3.1 & 0.0 & 1.5 & 0.98 \\
\hline Total Detrital $^{*}$ minerals (\%) & 49.5 & 58.4 & 87.4 & 66.8 & 75.5 \\
\hline Total Carbonates* minerals (\%) & 29.8 & 24.6 & 8.7 & 19.5 & 16.5 \\
\hline Total Sulfates * minerals (\%) & 9.7 & 8.0 & 1.8 & 5.3 & 2.6 \\
\hline K-Feldspar/Quartz* & 1.2 & 0.5 & 0.2 & 0.3 & 0.4 \\
\hline Glaucony.G & 6.8 & 10.4 & 0.4 & 0.0 & 16.6 \\
\hline Fossils of Foraminifera & 1.7 & 8.1 & 11.2 & 3.2 & 2.2 \\
\hline Quartz.G (\%) & 1.5 & 4.3 & 0.3 & 1.7 & 55.9 \\
\hline Feldspars.G & 0.3 & 0.0 & 0.0 & 0.0 & 4.6 \\
\hline Pyrite.g & 0.2 & 0.2 & 31.6 & 0.2 & 0.0 \\
\hline Pyritized Foraminifera & 0.0 & 0.0 & 8.9 & 0.7 & 0.0 \\
\hline Non-Biogenic Carbonates.G & 13.6 & 11.2 & 0.9 & 1.4 & 3.8 \\
\hline Well Preserved Benthic Foraminifera & 3.4 & 6.8 & 5.1 & 7.4 & 0.8 \\
\hline Well Preserved Planktonic Foraminifera & 1.3 & 3.9 & 1.9 & 18.7 & 2.5 \\
\hline Poorly Preserved Planktonic Foraminifera & 0.4 & 1.3 & 0.2 & 8.5 & 1.6 \\
\hline Ostracod Valves.G & 0.0 & 0.3 & 0.5 & 0.9 & 0.1 \\
\hline Pteropod Fragments.G & 0.1 & 0.5 & 0.3 & 4.0 & 0.1 \\
\hline
\end{tabular}

The SMGS also increases significantly and recurrently as a function of depth (Appendix 3) and gravel fraction values (Fig. 6 A). Higher percentages of gravel result in rising sorting values (Fig. $6 \mathrm{~B}$ ) that are related to poorly sorted and very poorly sorted sediments. These results reflect an irregularity of energy levels that can be related to geomorphological features and oceanic processes.

The fine fraction is mainly constituted by detrital minerals and carbonate, sulfate and sulfide (pyrite) minerals (Fig. $5 \mathrm{~A}$ and Appendix 1). In the fine fraction, among the detrital minerals, phyllosilicates are in general the most abundant group. Total Detrital* minerals tend to increase with depth (Fig. 8, Cluster 2; Table 1), such as Quartz*, but not the percentage of Phyllosilicates*, Plagioclase* and K-Feldspar* (as suggested by the correlations between these variables; Appendix 3). Total Carbonates* increases mostly in the intermediate region of the study area (Fig. 5 A). Calcite and aragonite contents may be mostly related to biogenic constituents (such as mollusk shells, ostracod valves, foraminiferal tests, corals and coralline algae).
The distribution pattern of the detrital minerals, carbonates and pyrite in both fine fraction and CSF is dissimilar (Fig. 5), which suggest that their composition is influenced by different factors.

Table 1 (from Q-mode CA) and R-mode CA (Fig. 8) results show that variables such as Total Sulfates* (Basanite*, Gypsum*) and Total Carbonates* (Calcite*, Aragonite*, Strontianite*) and Non-Biogenic Carbonates. G tend to occur in coarse grained sediments while Total Detrital* minerals, mainly Phyllosilicates*, and Total Biogenic. g particles tend to rise in finer grained sediments.

The sediment granulometry may be associated to the type of eroded material, transported and deposited and may be related to hydrodynamic conditions and other processes such as submarine landslides.

The bathymetry around $435 \mathrm{~m}$ seems to be a breakthrough for changes as a function of depth (Table 1). In sites shallower than $435 \mathrm{~m}$ (Cluster 1; Fig. 9), coarser grained sediments, enriched in Total Carbonates* and Total Sulfates*, Pyrite* and Non-Biogenic Carbonates.G occur. 


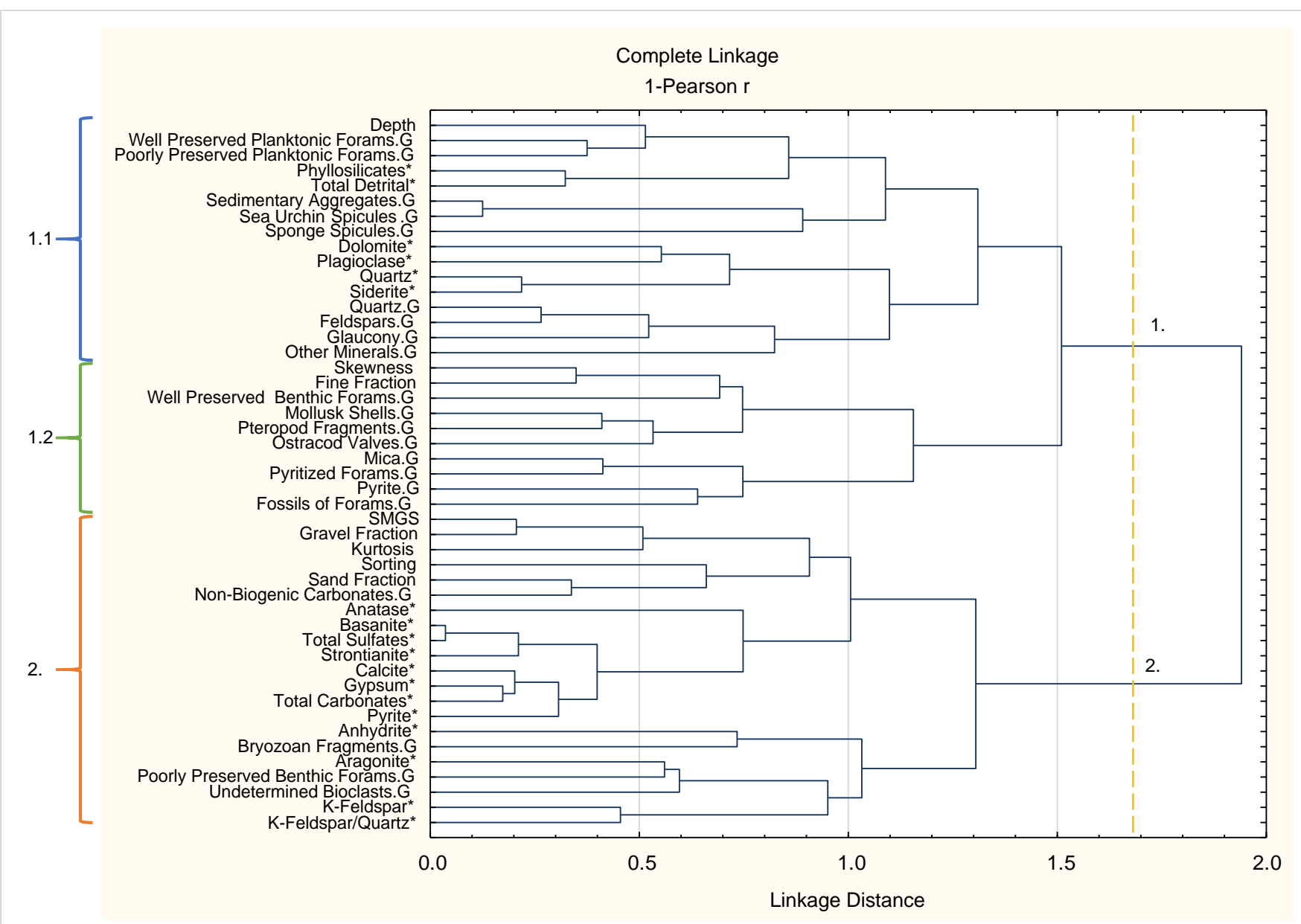

Fig. 8. R-mode Cluster Analysis based on textural, XRD-mineralogical variables (*; analyzed in Fine Fraction $(<63 \mu \mathrm{m}))$ and grains $(. G)$ of coarse sediment fraction $(250-500 \mu \mathrm{m})$ and depth. Legend. SMGS - Sediment Mean Grain Size $(\mu \mathrm{m})$; Forams. - Foraminifera (\%).

The higher relative abundance of Non-Biogenic Carbonates.g. associated with several mineralogical phases indicates super saturation of bottom waters in carbonates (Millero, 2006). The non-biogenic carbonates of CSF recurrently increase along the continental slope (Appendix 2) in an opposite pattern to that of biogenic carbonates (Fig. 8) suggesting that in some areas this type of organisms remains may be dissolved and reprecipitated in other sedimentary carbonate phases. The solubility of calcium carbonate in seawater is influenced by factors such as temperature, pressure and respiratory processes (Zeller and Wray, 1956). However, the saturation of bottom waters in carbonates seems to reduce in deeper stations $(435-1000 \mathrm{~m})$. Low temperature, high pressure and respiratory processes increase the solubility of calcium carbonate in seawater. The highest relative abundance of Pyrite* in shallower stations should be related to the accumulation of higher amount of organic matter in areas close to the nearby continental shelf. The transport of materials from the continental shelf to the deep ocean (carbonates and organic matter) seems to be reduced to offshore, as suggested by the decrease of Pyrite* and Pyrite.g in the deeper stations.

K-Feldspar/Quartz* values are relatively high in sites shallower than $435 \mathrm{~m}$ that suggest the arrival of less weathered materials. The K-Feldspar/Quartz* shows positive correlations with Anatase*, Aragonite*, Basanite*, Calcite*, Total Carbonates*, Total Sulfates* and Pyrite*. These correlations indicate that most of these minerals are probably sourced from the same areas and may correspond to materials supplied by the rivers to the ocean or removed from the adjacent continental shelf. These areas may also be an additional source of organic matter whose degradation promotes the formation of pyrite, as refereed.

\subsection{Detrital minerals in the study area}

The results of R-mode Cluster Analysis (Fig. 8) indicate that the relative abundance of detrital minerals both in CSF and in fine fraction, are mainly related to fine grained sediments and depth (Cluster 1). This mean that in general 
the carbonated component is more important in shallower stations of continental slope. This is apparently contradictory. It is expected that great amount of lithogenic sediments reach the shallower areas of the continental slope than deeper ones due to the sediments introduced into the continental shelf by the rivers runoff and processes of transport to the deep ocean.

Total Detrital.G minerals in CSF significantly increase $(>10 \%)$ in a reduced number of sites $(1,9,11,12,23,27,28$, 46 and 50), being particularly high (between 30-85\%) at sites $9,23,28$ and 1. The lithogenic particle variety is however reduced (including mainly quartz) at these sites and co-occurs with more or less high proportions of Glaucony.g and Fossils of Foraminifera, except at site 1, where the Total Detrital.G minerals reach 34\% (composed mainly by "Other Minerals"; Appendix 2).

Fine grained sediments, composed mainly by phyllosilicates, are mostly supplied to the study area. The obtained results indicate that these materials are deposited and remobilized several times before to be accumulated in calm and protected zones. Regional climatic characteristics should favor the introduction of sediments in the oceanic system. Despite the density of the hydrographic network in the region, rivers are small. The only significant continental input of water and sediments are derived from the São Francisco River (river mouth location: $10^{\circ} 36^{\prime} \mathrm{S}$ ), which drains at north of the study area.

The coarse-grained sediments brought by the rivers flow to the oceanic settings are probably restricted to shallower areas of the continental shelf from which they can be removed by the waves and transported for the longshore drift. The presence of coral reefs in the nearby continental shelf should cause interferences on hydrodynamics and sediment dispersion patterns. According to Martin et al. (1999), reefs disturb the action of the waves in the coastal stretches in front of them, causing deviations towards the wave fronts. Landslides at the continental slope may introduce or remove sediment in some areas. All these interferences have implications on the characteristics and composition of continental margin sediments.

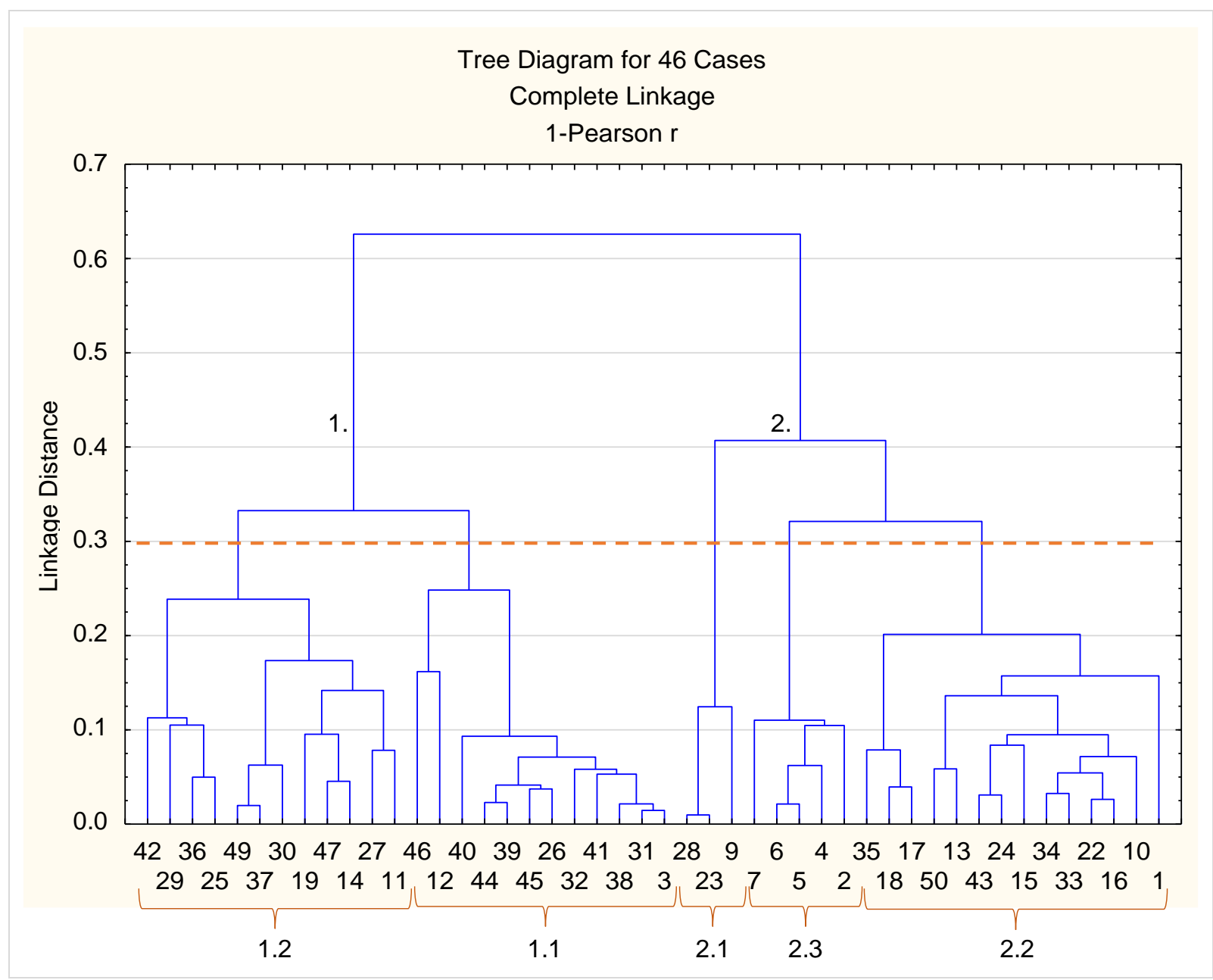

Fig. 9. Q-Mode Cluster analyses (CA), based on the same selected textural, DRX-mineralogical and compositional variables of grains of coarse sediment fraction (CSF). 
Relatively high levels of phyllosilicates also occur at sites with the highest percentages of gravel (e.g., sites 11, 12, 39, 44 and 47), where these minerals may be associated with former sedimentary transport cycles or to erosion of older sedimentary deposits.

The K-Feldspar/Quartz* (K-Fd/QZ) ratio is used, in this work, to identify changes in the proximity of sediment sources. As quartz is a more resistant mineral to erosion than feldspar, this ratio allows to identify "fresh" sediments, little altered or weathered and essentially constituted by quartz. This ratio is expected to be higher at sites receiving sediments from nearby sources or newly eroded sediment particles, and not subject to several sediment cycles, considering that $\mathrm{K}$ feldspar degrades much faster than quartz.

The values of this ratio are particularly high at some sites (Fig. 4 C) such as 40 (at $110 \mathrm{~m}$ deep; K-Fd/QZ: 8.8), 37 (at $260 \mathrm{~m}$ deep; K-Fd/QZ: 2.0), 39 (at $90 \mathrm{~m}$ deep; K-Fd/QZ: 1.3), and 29 (at $260 \mathrm{~m}$ deep; K-Fd/QZ: 1.3), in association with relatively coarse sediments (Appendix 1) and should be associated with erosion of adjacent rock outcrops. However, the values of the K-Feldspar/Quartz* ratio are generally low $(\leq 0.5)$, which mean that in most of the sites the lithogenic particles experienced several transport cycles and are significantly weathered.

\subsection{Evaporitic Minerals Identified in the Study Area}

Calcium-sulfate minerals such as anhydrite $\left(\mathrm{CaSO}_{4}\right)$, basanite, $\left(\mathrm{CaSO}_{4} \cdot 0.5 \mathrm{H}_{2} \mathrm{O}\right)$, and gypsum $\left(\mathrm{CaSO}_{4} \cdot 2 \mathrm{H}_{2} \mathrm{O}\right)$ are common sedimentary minerals found in marine evaporite sequences (Dyar et al., 2008; Prothero and Schwab, 2004). In the study area, gypsum and basanite have significant positive correlations between each other (Fig. $7 \mathrm{E}$ and Appendix 3), which should mean a common source.

Gypsum is one of the first minerals precipitated from seawater of normal salinity, at temperatures below $60^{\circ} \mathrm{C}$, because $\mathrm{Ca}^{2+}$ and $\mathrm{SO}_{4}^{2-}$ are less soluble than other ions (Conley and Bundy, 1958). Anhydrite is generally originated at relatively higher temperatures and increased $\mathrm{Ca}^{2+}$ and $\mathrm{SO}_{4}{ }^{2-}$ brine concentration (Hardie, 1967; Billo, 1987; Deer et al., 1992). They can also be found in hydrothermal environments (Deer et al., 1992). Basanite is also characteristic of dry marine evaporitic environments (Gunatilaka et al., 1985). Thus, these minerals should have been formed at least in part during the seawater evaporation in the sample preparation for the mineralogical analysis and are probably related to abundant dissolved sulfates in seawater of the study area.

However, Anhydrite*, Basanite* and Gypsum* have significant positive correlations with Fossils of Foraminifera and Gravel Fraction of the sediments. The Gravel Fraction is mostly composed by biogenic components where fragments of corals and coralline algae, supplied probably from the adjacent continental shelf, are common. These relationships should indicate that they can also be related to phases of sea level drop when the coastline was closer to the study area and the oceanic processes allowed the transport of large particles removed from adjacent areas and deposited on the upper slope region.

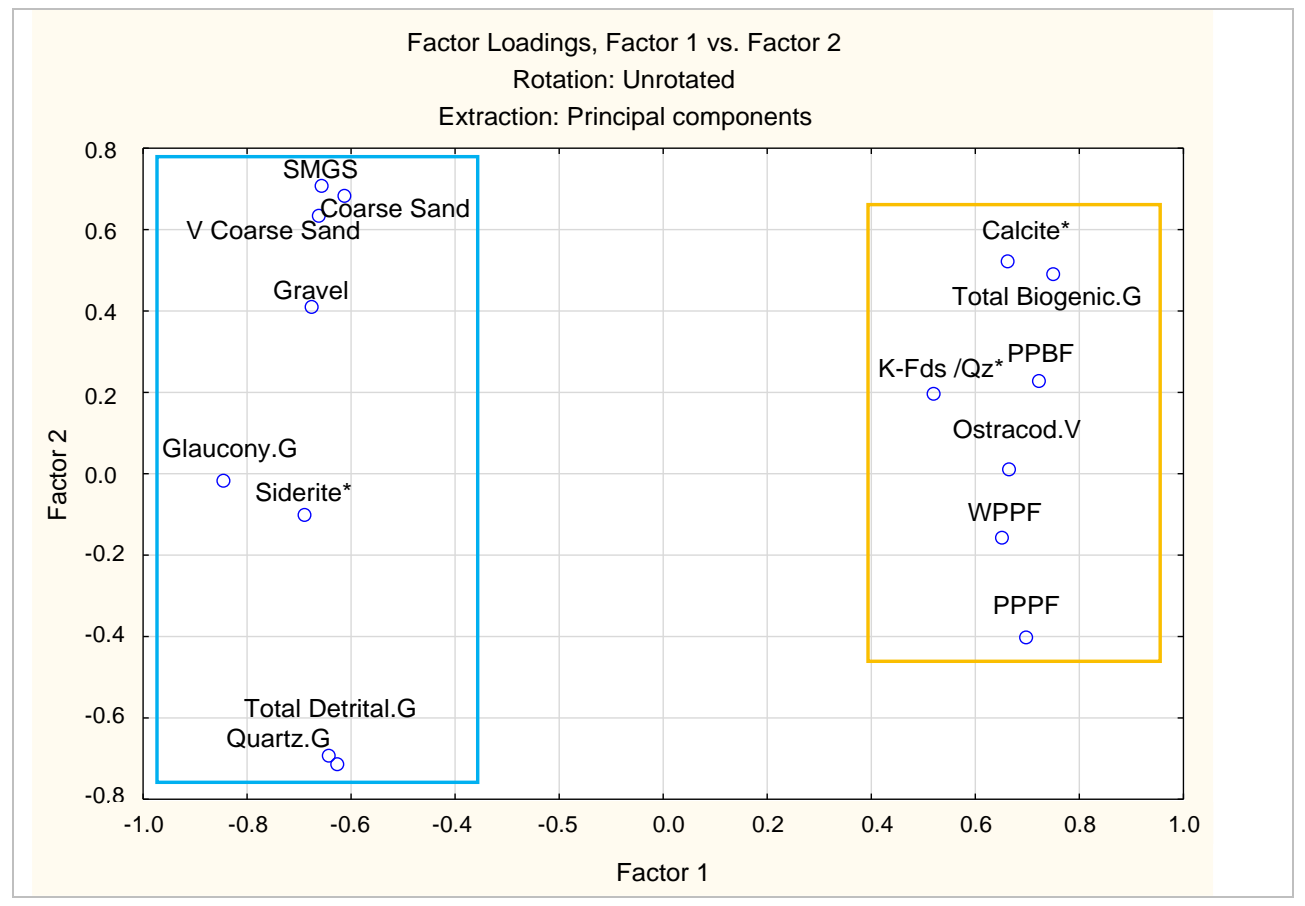

Fig. 10. PCA factor plan based on the selected variables by their significant correlations with glaucony. 


\subsection{Sulfide Minerals in the Study Area}

Pyrite $\left(\mathrm{FeS}_{2}\right)$ is much common in fine fraction where it is present in most of the samples whereas was only found in some sites in CSF. Pyrite.g occurs mostly as granular masses, framboids and foraminiferal infillings in CSF. Considering the characteristics of pyrite grains present in SCS, we can deduce that this mineral was originated from initial diagenetic processes of degradation of organic matter in anoxic environments and/or microenvironments. The highest abundance of Pyrite.G in CSF is found in sites 4-7 (Fig. 5 B), at the northern part of the study area (Cluster Analysis subarea 2.3; Fig. 9) and should be related to the highest contribution of organic matter to the ocean supplied by São Francisco River, located at north.

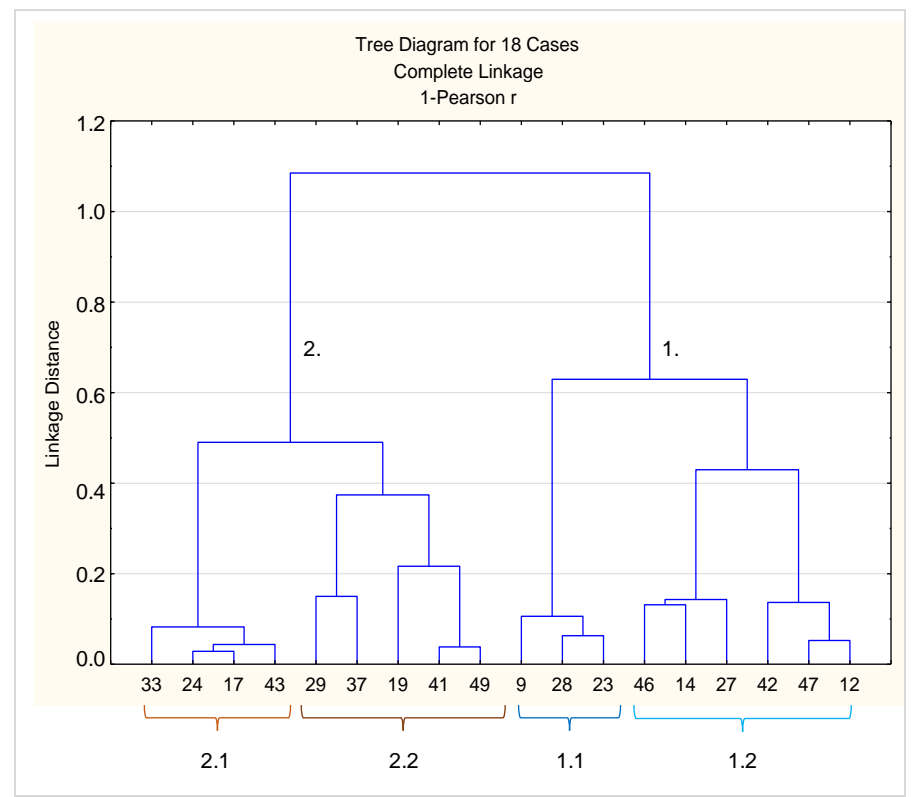

Fig. 11. Q-Mode CA based on the same variables of PCA (Fig. 10).

According to Berner (1984), the rates of supply of decomposable organic matter, dissolved sulfate and reactive detrital iron minerals are conditioning factors that control the amount of pyrite formed in a sediment. From these factors, organic matter seems to be the major control on pyrite formation in terrigenous marine sediments where dissolved sulfate and iron minerals are abundant (Berner, 1984). Sulfates and iron-rich minerals seems to be abundant in the upper slope of the Jacuípe Basin, as indicated by the presence of anhydrite, gypsum and basanite and high percentage of phyllosilicates.

Although the study area has been considered oligotrophic since the average annual primary productions varies up to 50-100 $\mathrm{g} \mathrm{Cm}^{-2} \mathrm{yr}^{-1}$ (Marone et al., 2010), upwelling processes occur at the shelf edge (Ekau and Knoppers, 1999). The offshore banks and few small islands and rocks also can
RESEARCH PAPER

develop local upwelling effects (Ekau and Knoppers, 1999). Organic matter produced in the nearby continental shelf and reefs may be also transported offshore and deposited in some favorable areas. The accumulation of organic matter can give rise to reducing microenvironments where anaerobic bacteria may reduce dissolved sulfate in seawater, initiating the formation of $\mathrm{H}_{2} \mathrm{~S}$ (Berner, 1970; Rickard, 1995). The $\mathrm{H}_{2} \mathrm{~S}$ reacts with iron minerals present in the sediment to form $\mathrm{FeS}$ (Siesser and Rogers, 1976; Luther, 1991; Rickard, 1997).

Pyrite* is positively correlated with Calcite* and is mainly present in shallower stations. This indicates that part of organic matter received in the upper slope of the Jacuípe Basin is probably supplied from the biological productivity in adjacent continental shelf where there are extensive areas of coral reefs, which constitute sources of carbonates to this region. The presence of organic matter allows the development of communities of organisms such as mollusks and foraminifera that also contribute with carbonates to the sediment.

\subsection{Carbonate minerals in the study area}

Carbonate minerals are represented by Aragonite*, Calcite*, Dolomite*, Siderite* and Strontianite*. Aragonite* $\left(\mathrm{CaCO}_{3}\right)$ is identified in few (12) sites. It is common in almost all mollusk shells, in calcareous endoskeleton of corals, in some aragonitic tubes of sessile Polychaeta, in some species of foraminiferal tests and pteropod shells, from which it should have been supplied to the fine fraction. It can be also formed in the ocean and in caves as inorganic precipitates called marine cements and speleothems, respectively (Runnegar, 1987). Aragonite* concentrations reduce significantly with depth (Fig. 7A).

Dolomite* $\left(\mathrm{CaMg}\left(\mathrm{CO}_{3}\right)_{2}\right)$ is identified in most of the sites of the study area. This mineral has significant positive correlation for instance with Siderite* and Glaucony.G that should indicate that this mineral may have been inherited and/ or formed secondarily. According to Warren (2000), dolomite can form as a primary precipitate, a diagenetic replacement, or as a hydrothermal/metamorphic phase. Krause et al. (2012) noticed that Desulfobulbus mediterraneus, a marine sulfate-reducing bacterium, can mediate primary precipitation of $\mathrm{Mg}$-rich dolomite under anoxic conditions in laboratory experiments simulating modern seawater chemistry at low temperature $\left(21^{\circ} \mathrm{C}\right)$.

According to Deer et al. (1992), secondary dolomite can be formed from limestones, in which magnesian solutions penetrated through rock faults and diaclases. In the study area, the magnesium for dolomitization would have been derived from seawater, being the time factor of considerable importance.

Deer et al. (1992) also mentioned the hypothesis of dolomite may be formed from fragments of carbonate shells 
(calcite or aragonite). According to Rothwell (1989), the genesis of dolomite in marine sediments is controlled, not by the ratio of $\mathrm{Mg}^{2+} / \mathrm{Ca}^{2+}$ in seawater, as previously thought, but by dissolved sulfate, which inhibits the formation of this mineral. In the absence of this ion, the seawater reacts rapidly with calcite and aragonite to form dolomite. One of the most common processes for the removal of sulfate is its bacterial reduction to hydrogen sulfide in marine sediments rich in organic matter. However, the correlation between Dolomite* and Pyrite* is low and not significant in the analyzed sediments. The highest relative abundance of Dolomite* is not always coincident with the occurrence of Pyrite* and Pyrite.G in the sediments, and relatively high abundance of sulfate minerals. So, it can be deduced that Dolomite* should be mostly inherited at least in the sites where this mineral reaches the highest percentages (2, 9, 14, 28 and 49).

Siderite $\left(\mathrm{FeCO}_{3}\right)$ occurs in metamorphosed iron formations, altered igneous rocks, including the upper oceanic crust (lavas) (Klein, 2005; Kholodov and Butuzova, 2008; Kang et al., 2016) and in hydrothermal veins (Morris et al., 2010). Siderite* has significant positive correlations with several variables such as Depth, Dolomite*, Plagioclase* Quartz* and Quartz.G which means that it was supplied probably from the erosion of igneous rocks jointly with the other minerals. Siderite* has also significant positive correlations with Glaucony.g and Fossils of Foraminifera*. These data indicate that the increase of Siderite* is associated with older sediments.

Strontianite $\left(\mathrm{SrCO}_{3}\right)$ is present in most of the analyzed sites. It has significant positive correlations with Anhydrite*, Aragonite*, Basanite*, Calcite*, Gypsum*, Pyrite*, Total Carbonates*, Total Sulfates* and K-Feldspar/Quartz*. The correlations suggest that Strontianite* are related to the other carbonates and sulfates and with modern sedimentary particles. According to some authors a variety of corals can precipitate a metastable, strontium-supersaturated aragonite with strontianite (Finch and Allison, 2003; Finch et al., 2003; Allison et al., 2005). This biogenic component can also be a source of this mineral to the study area. The positive correlation of Strontianite* and Pyrite.g and Non-Biogenic Carbonates.G also suggests the occurrence of neoformation of this mineral. It is admitted that co-precipitation of $\mathrm{Sr}^{2+}$ can occur in calcite and aragonite (Kinsman and Holland, 1969; Schroeder, 1969) but it is yet a subject under study (Möller and Pistorius, 2007). Strontianite is however common in carbonatites and is frequently associated with hydrothermal deposits or pegmatites (Palache et al, 1951; Speer and Hensley-Dunn, 1976; Jarosch, and Heger, 1988). Under appropriate conditions, it can be found as an alteration from Celestine ( $\mathrm{SrSO}_{4}$; Palache et al., 1951). Carbonate phases as well as sulfate phases may occur in evaporites and hydrothermal veins (Ure and Berrow, 1982) and these can also be sources of these minerals to the study area.

\subsection{Glaucony in the study area}

Glaucony.g was found in 18 scattered sites, between 170$780 \mathrm{~m}$ water depth (Appendix 2), either as irregular sedimentary grains or internal fills of foraminiferal tests and shells of other organisms. The negative correlations of Glaucony.g with carbonate protections of organisms, such as foraminiferal tests and ostracod valves (Appendix 3) suggest that the carbonate protections of these organisms should be involved in the formation process of this mineral. According to Odin and Matter (1981), the glauconitic crystals as they grow dissolve the substrate, which disappears by dissolution. The first stage of this mineral formation corresponds to the first development of glauconitic minerals rich in Fe, mainly Fe rich smectite (Odin and Matter, 1981). Clay minerals analysis was not carried out in this study and, therefore, it is not possible to ensure the presence of smectite in the study area.

However, according to Odin and Matter (1981), the mechanism of glauconitization occurring in the sedimentwater interface, requires favorable environmental conditions, such as low sedimentation rates, environments or microenvironments where there is sufficient organic matter, slightly alkaline $\mathrm{pH}$ and high concentration of relevant chemical elements, namely Fe and K. Glaucony maturation includes progressive incorporation of potassium and iron and change of mineralogical structure toward an end member constituted by a non-expandable, K-rich glauconitic mica (Odin and Matter, 1981; Odin and Fullagar, 1988), namely glaucony (Burst, 1958; Hower, 1961).

Thus, glaucony is usually considered an authigenic marine product and is commonly associated with transgressive deposits and condensed sections (Odin and Matter, 1981; Amorosi, 1995, 1997; Amorosi and Centineo, 1997; Kitamura, 1998; Chattoraj et al., 2009; Harris and Whiting, 2000; Banerjee et al., 2012a, b).

Glaucony occurs typically in sedimentary rocks ranging in age from the Late Paleoproterozoic to the Holocene in forms of 60-1000 $\mu \mathrm{m}$ green clay aggregates (Odin and Matter, 1981; Dasgupta et al., 1990; Amorosi et al., 2007, 2012; Amorosi, 2012; Lee et al., 2002; El Albani et al., 2004; Bandopadhyay, 2007; Banerjee et al., 2008, 2015; Chattoraj et al., 2009). Glaucony forms in a wide variety of substrates including fecal pellets, bioclasts, feldspar, mica and quartz (Banerjee et al., 2016).

The maturity level (evolution) reached by glauconitic mineral depends on the residence time of grains close to the sediment water interface, under low sedimentation rates. The residence time of highly evolved glaucony grains is estimated to be $10^{5}-10^{6}$ years (Banerjee et al., 2016). During the maturation process, glaucony color becomes darker (Amorosi, 1997, 2012). The presence of evolved glaucony is generally considered as a proxy for significant breaks in 
sediments deposition (McRae, 1972; Odin and Matter, 1981; Odin and Fullagar, 1988; Amorosi, 2012).

For the glaucony maturity Amorosi (1995) proposed the following stages: nascent, slightly evolved, evolved, and highly evolved. In the study area Glaucony.G has in most of the sites (where it was found) light green color and slightly evolved aspect when compared to that observed for example in the outer continental shelf and upper slope of Iberian Continental Margin (Martins et al., 2012).

According to Amorosi (1995) the glaucony origin can be autochthonous and allochthonous. Autochthonous glaucony has not experienced significant transport from its place of formation. For the allochthonous origin, this author also considered two other divisions: parautochthonous and detrital. Detailed sedimentological studies including facies interpretation of glaucony-bearing deposits and careful examination of spatial distribution of glaucony, not entirely contemplated in this study, are necessary to detect autochthonous vs allochthonous glaucony (Amorosi, 1997). However, some indications can be obtained from our results. The PCA considering only the 18 stations (Fig. 11) where glaucony was recorded, evidence the correlations (Appendix 4) of this mineral with selected variables (by their significant correlations).

Glaucony.g has significant positive correlation with SMGS, namely coarse grain fractions, such as gravel, very coarse and coarse sand fractions and mainly occurs in coarse grained sediment. Glaucony.g has also significant positive correlations with Total Detrital.G minerals, including for instance Quartz.G, Siderite* (Appendices 3, 4); co-occurs in general with Fossils of Foraminifera, Pyrite* and Pyrite. $G$ (Appendices 1 and 2) and shows significant negative correlations with K-Feldspar/Quartz*, Calcite*, Total

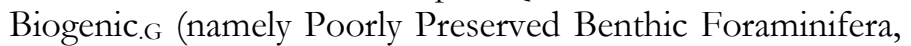
Well Preserved Planktonic Foraminifera, Poorly Preserved Planktonic Foraminifera). These correlations are clearly expressed in PCA (Fig. 10). Using the same variables, the QMode CA separates two main clusters and sub-clusters of stations (Fig. 11).

Relatively high percentages of Glaucony.g are found at sites 9 (at $670 \mathrm{~m}$ deep), 23 (at $651 \mathrm{~m}$ deep) and 28 (at $650 \mathrm{~m}$ deep), grouped in sub-cluster 1.1 of CA (Fig. 11). In these sites Pyrite*, Pyrite.g and Pyritized Foraminifera were not found. Despite pyrite be produced in sub-surface and glaucony at the interface water-sediments, for the formation of both minerals it is necessary the deposition of significant amount of organic matter and reducing environments. The absence of pyrite may reveal less favorable conditions to the accumulation of organic matter. These conditions are also unfavorable to the occurrence of glauconitization. The stations of sub-cluster 1.1 are associated with low values of K-Feldspar/Quartz* that indicates the presence of weathered sediments. Calcite*, Total Biogenic.g, and Total Carbonates* are the lowest in these sites but Total Detrital.G and Total Detrital* minerals contents are the highest and contain relatively high proportion of Siderite* (probably supplied from the erosion of igneous rocks). It was expected that the biogenic component is higher than the lithogenic one in both fractions at about 650-670 $\mathrm{m}$ deep. So, we can infer that carbonates were "diluted" by terrigenous materials.

Glaucony occurs in general in marine shelf and slope deposits, at an average depth between about $50 \mathrm{~m}$ and $500 \mathrm{~m}$ (Odin and Fullagar, 1988) and its formation in deeper-water locations seems to be quite uncommon (Odin and Stephan, 1981; Odin and Frölich, 1988). In these stations the sediment is fine grained (mean SMGS: $23.3 \mu \mathrm{m}$ ) and the glaucony grains are not in hydraulic equilibrium with most part of sedimentary particles. Thus, we can deduce that glaucony grains are probably transported from shallower areas through offshore transport mechanisms, probably through slope fan lobes jointly with other populations of lithogenic particles. Thus, Glaucony.g present in sites 9, 23 and 28 is probably detrital.

As in the previously mentioned sites (9, 23, 28), the SMGS is also small (mean: $25 \mu \mathrm{m}$ ) in the stations of sub-cluster 2.1 of CA (Fig. 11): 33 (at 300 deep), 24 (at $640 \mathrm{~m}$ deep), 17 (at $780 \mathrm{~m}$ deep), 43 (at $667 \mathrm{~m}$ deep). However, in these stations both fine grained sediments and CSF are enriched in carbonates; the fine fraction presents mean values of detrital minerals identical to the other groups of stations with glaucony (identified by Q-Mode CA; Appendix 4). In the stations of sub-cluster 2.1 (33, 24, 17 and 43), the mean KFeldspar/Quartz* ratio is about 0.5, which means that the sediments may include more or less weathered lithogenic sediments. These sites include higher percentages of biogenic carbonated particles (namely Undetermined Bioclasts, Poorly Preserved Benthic and Planktonic Foraminifera). Moreover, the percentage of Glaucony.g (mean $1.6 \%$ ) is quite low. In these sites (33, 24, 17 and 43), Glaucony.g should have been removed from their place of origin, and concentrated both landward and seaward within nearly coeval deposits ('contemporary' reworking) and is probably parautochthonous, according to Amorosi (1995). The transport process should have been different from the stations of sub-cluster 1.1 of CA (Fig. 9; stations 9, 23 and 28), given the highest abundance of biogenic carbonated component of CSF.

The stations of sub-cluster 2.2 of CA (Fig. 11), 19 (at 657 $\mathrm{m}$ deep), 29 (at $260 \mathrm{~m}$ deep), 37 (at $260 \mathrm{~m}$ deep) and 41 (at $260 \mathrm{~m}$ deep), have high sorting values (mean 4.4), that is, the sediments are very poorly sorted and relatively coarse (mean SMGS $106.2 \mu \mathrm{m})$, the values of skewness show strong asymmetry in the direction of the coarse-grained particles. The increase in grain size is caused by biogenic carbonated particles, including for instance significant percentages of Fossils of Foraminifera, Poorly Preserved Benthic Foraminifera and Undetermined Bioclasts, corresponding to transported material. The K-Feldspar/Quartz* ratio reaches 
relatively high values up to 2.0 (mean 0.8 ), indicating the presence of "fresh", slightly weathered lithogenic materials probably introduced through the rivers in the ocean system. So, given the high abundance of biogenic carbonated component of CSF, and the mineralogical composition of fine fraction, it can be assumed that this transport was carried out under suspended load and bed load through the slope. In these sites Glaucony.g are probably detrital too.

At stations of sub-cluster 2.2 of CA (Fig. 11), 12 (at 615 $\mathrm{m}$ deep), 14 (at $680 \mathrm{~m}$ deep), 27 (at $260 \mathrm{~m}$ deep), 42 (at 450 $\mathrm{m}$ deep), 46 (at $390 \mathrm{~m}$ deep) and 47 (at $450 \mathrm{~m}$ deep), Siderite*.

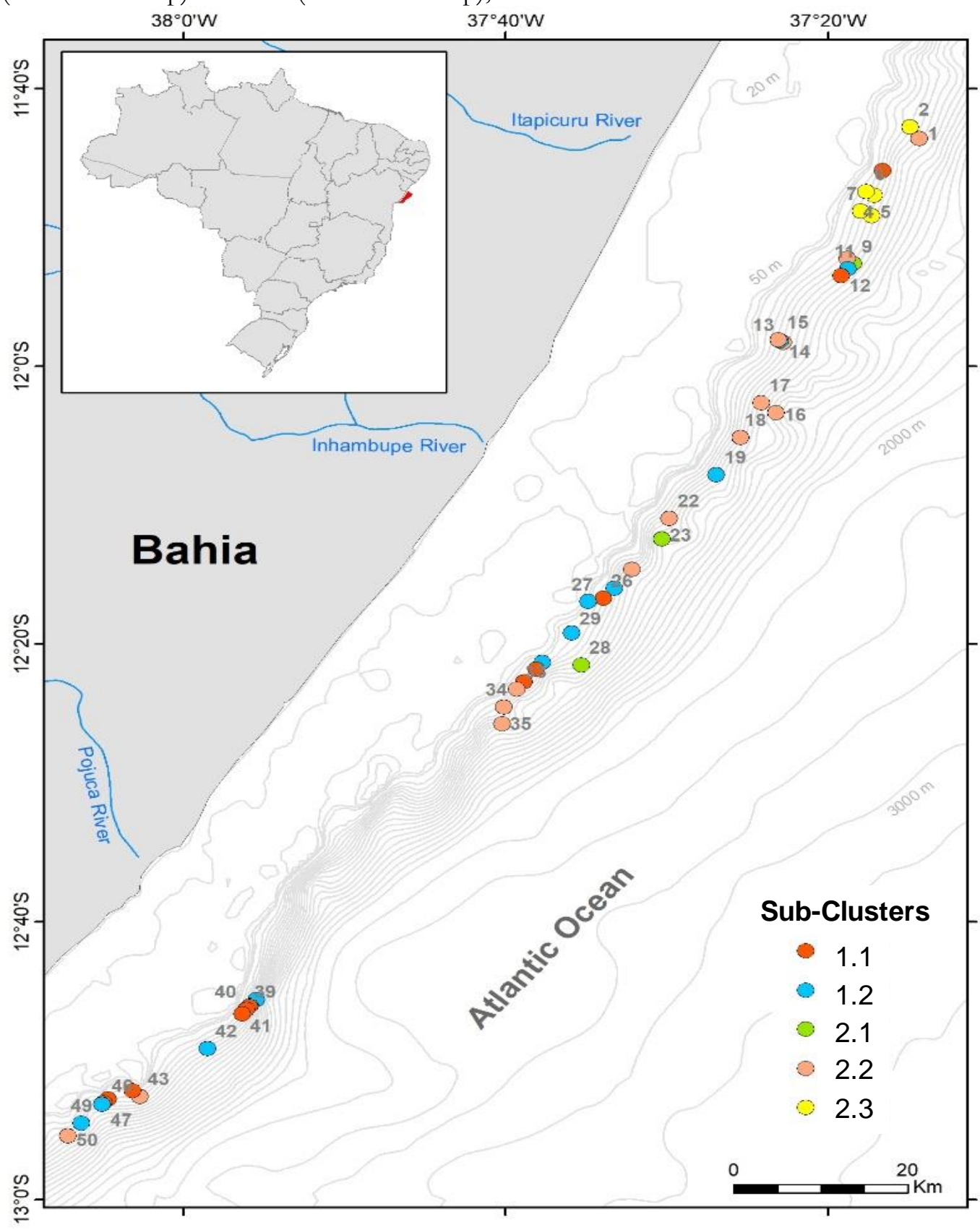

Fig. 12. Map of the sites related to the five sub-clusters identified in Figure 9.

sediments are coarse grained (mean SMGS: $474.2 \mu \mathrm{m}$ ) and poorly to poorly sorted, which mean that they experience quite energetic hydrodynamical processes. In these stations, high contents of Glaucony.g (mean $27.6 \%$ ), Pyrite* (mean $4.2 \%$ ), Siderite* $(5.5 \%$ ) and Fossils of Foraminifera (mean $10.2 \%)$ are found. These samples are characterized by the lowest K-Feldspar/Quartz* values (mean 0.2) that indicate the presence of weathered terrigenous particles in fine fraction deposited in an ancient period. This is also indicated by the relative abundance of Fossils of Foraminifera and 
Site 12 (at $615 \mathrm{~m}$ deep) has the highest relative abundance Glaucony.g (49.4\%). This site is characterized by: the highest value of SMGS; all the sedimentary particles are glauconitized; absence of Well-Preserved and Poorly Preserved Benthic and Planktonic Foraminifera; relatively low percentages of Quartz.G, Feldspars.G and low value of KFeldspar/Quartz* and; significant proportions of Pyrite.G and Fossils of Foraminifera. The low value of $\mathrm{K}$ Feldspar/Quartz* ratio indicates the presence of weathered sediments subject to several sedimentary cycles. The presence of Pyrite.g suggests a significant contribution of organic matter that allowed the formation of glaucony. Examples of enrichment of glaucony in relic deposits are known in several regions of the globe (Bornhold and Giresse, 1985; Lim et al., 2000; Martins et al., 2012) and are most likely the result from erosion by waves and reworking of sediments.

The highest proportion of Fossils of Foraminifera is found in site 42 (at $450 \mathrm{~m}$ deep) in coincidence with relatively high percentage of Glaucony.g (Appendix 2). Site 49 (at 260 $\mathrm{m}$ deep) has significant proportion of Glaucony.g (23.2 \%) and Fossils of Foraminifera (6-9 \%), being the CSF only constituted by carbonated particles. In sites 42 and 49 , the fine fraction is composed essentially by Total Detrital* minerals, but has very low K-Feldspar/Quartz* values. These data suggest that the mineralogical component of the sediment was subjected to multiple sedimentary cycles. Similar characteristics are observed for instance in sites 14, 27, 46 and 47, characterized by very low K-Feldspar/Quartz* values and significant proportions of Glaucony.g and/or Fossils of Foraminifera.

Glaucony.g present in stations $12,14,27,42$, 46, and 47 (at $450 \mathrm{~m}$ deep), seems to be also detrital but formed in older sedimentary environments and are probably relic particles. The deposit in all these areas should be constituted essentially by "relic" sediment accumulated at earlier times and under different conditions.

\subsection{Sedimentological changes as a function of depth and latitude}

It is expected that in the different stretches of the Brazilian Continental Margin the characteristics of the sedimentary cover change considering the adjacent continental geology, the rivers that flow to the coast, the climatic, geomorphological characteristics of the emerged and submerged regions and hydrodynamic changes that vary significantly in intensity and pattern.

According to McManus (1975), it is possible to classify the sedimentary deposits existing in continental margins by using relationships between the processes of supply and distribution of the particles. Thus, modern deposits of current formation, which depend on the type of particles they form, may correspond to neoteric (modern particles), proteric (old particles) and amphoteric (modern and old particles) sediments (McManus, 1975). Proteric deposits are solely constituted by relic particles, not current, and palimpsest deposits when the sediments are composed of relic and modern particles (McManus,1975).

From the above, it can be deduced that the stations belonging to Q-Mode CA (Fig. 9):

- Sub-cluster 1.1 correspond to places where erosion of sediment is mainly occurring; at least in sites 12 and 46 where relic sediments arise.

- Sub-cluster 1.2 correspond to places of reduced deposition of sediments with predominant relict or palimpsest sediments, composed of both "modern" and "relic" particles, according to the conception of Swift et al. (1971).

- Sub-cluster 2.1 correspond to sediments transported to deeper zones of the continental slope by landslides. These sites are situated in the central and northern region of the study area where the depositary has amphoteric sediments.

- Sub-cluster 2.2 are places of deposition of sediments transported along the slope, from shallower areas; in some places, the depositary has mostly modern particles, in the conception of de Curray (1965), in equilibrium with the current supply processes; in other places the depositary is composed mostly by amphoteric particles.

- Sub-cluster 2.3 located at the northern area, may have sediments introduced in the oceanic system by the São Francisco River outflow.

The spatial distribution of the stations (Fig. 12) belonging to each of the mentioned sub-clusters (Q-Mode CA; Fig. 9) allows to verify an intercalation of sites where hydrodynamic conditions are favorable to sediments deposition (sub-cluster 2.2) and to erosion or reduced sediment deposition (subclusters 1.1, 1.2). Erosion/reduced sediment deposition zones are more frequent in the central and southern part of the study area, while the northern region seems to be more favorable to sediment accumulation.

Two main factors may contribute to this pattern. The proximity of an important source of sediments for the oceanic system, the São Francisco River, and the origin and formation process of Brazil Current (offshore). It is possible that the action of this current is weaker in the region near its place of origin and becomes more effective in the southern region.

The effect of NBUC may also be considered significant. Other factors that may influence this pattern may be the activity of the NBUC, the effects caused by the internal solitary waves, commonly generated near the shelf edge (Shanmugam, 2013), vortices induced by geomorphological irregularities, turbidity currents caused by collapsing slopes and other geological disturbances (Meiburg and Kneller, 2010) or sedimentary mass movements on the continental slope. 


\section{Conclusion}

The textural, mineralogical and compositional results presented in this study evidence the occurrence of longitudinal (as a function of depth) and latitudinal changes of surface sediments at the upper continental slope of the Jacuípe Basin. The mineralogical and compositional data of sediments suggest that waters at the seafloor are enriched in sulfates and carbonates leading to the formation or preservation of several sulfated and carbonated mineralogical phases, mostly in shallower depths $(<435 \mathrm{~m})$. The carbonate saturation seems to reduce with depth, where aragonite and pteropod fragments become rare, but a significant proportion of well-preserved planktonic foraminifera in the deepest sites remain still significant. Pyrite.g is more abundant in the northern area, closer to the São Francisco River outflow, indicating that the deposition of organic matter supplied from continental areas should be more important in this region. However, regardless oligotrophic conditions, the occurrence of Pyrite* in most of the sites even in the upper slope suggests the presence of significant amounts of organic matter supplied by the continent or primary productivity on the continental shelf. The influence of the São Francisco River is well marked in the north and center parts of the study area, which are also more favorable to sediments accumulation being the low sediment deposition and erosive character clearly marked to the south.

Glaucony.g should be mostly detrital and parautochthonous; in some places it seems to be associated to modern sedimentary processes but in some places the presence of this mineral reveals the occurrence of relic sediments related to older sedimentary environments.

Changes in the bottom morphology and hydrodynamic conditions, namely the activity of Brazil Current, which is formed at the northern area and the NBUC may explain the major latitudinal and longitudinal changes. At about $435 \mathrm{~m}$ deep, considerable changes in the mineralogical composition of the sediments are observed, which should be associated with a greater influence of NBUC.

\section{Acknowledgment}

The authors would like to thank the Nacional do Petróleo e Biocombustível (ANP, Brazil) by yielding the samples and to the research funding agency "Fundação para a Ciência e a Tecnologia" (FCT, Portugal) by the support given through the strategic project UID/GEO/04035/2013. The first author also would like to thank CNPq (National Council of Scientific and Technological Development, Brazil) for the productivity fellowship (number 301588/2016-3).

Appendices 1-4 are attached as supplementary materials (SM1SM4) in http://www.e-

publicacoes.uerj.br/index.php/jse/article/view/32493

\section{References}

Allison, N., Finch, A.A., Newville, M., Sutton, S.R., 2005. Strontium in coral aragonite: Sr coordination and geochemistry in relation to skeletal architecture. Geochimica et Cosmochimica Acta 69, 3801-3811. https://doi.org/10.1016/j.gca.2005.01.026

Amorosi, A., 1995. Glaucony and sequence stratigraphy: A conceptual framework of distribution in siliciclastic sequences. Journal of Sedimentary Research B65: 419-425. https://doi.org/10.1306/D4268275-2B26-11D78648000102C1865D

Amorosi, A., 1997. Detecting compositional, spatial, and temporal attributes of glaucony: a tool for provenance research. Sedimentary Geology 109, 135-153. https://doi.org/10.1016/S0037-0738(96)00042-5

Amorosi, A., Centineo, M.C., 1997. Glaucony from the Eocene of the Isle of Wight (southern UK): implications for basin analysis and sequence stratigraphic interpretation. Journal of the Geological Society of London 154, 887896. https://doi.org/10.1144/gsigs.154.5.0887

Amorosi, A. 1997. Detecting compositional, spatial, and temporal attributes of glaucony: a tool for provenance research. Sedimentary Geology 109, 135-153. https://doi.org/10.1016/S0037-0738(96)00042-5

Amorosi, A., Sammartino, I., Tateo, F., 2007. Evolution patterns of glaucony maturity: a mineralogical and geochemical approach. Deep-Sea Research Part II: Topical Studies in Oceanography 54, 1364-1374. https://doi.org/ 10.1016/j.dsr2.2007.04.006

Amorosi, A., 2012. The occurrence of glaucony in the stratigraphic record: distribution patterns and sequence stratigraphic significance. International Association of Sedimentologists Special Publications 45, 37-54.

Amorosi, A., Guidi, R., Mas, R., Falanga, E., 2012. Glaucony from the Cretaceous of the Sierra de Guadarrama (Central Spain) and its application in a sequence stratigraphic context. International Journal of Earth Sciences 1, 415-427. https://doi.org/10.1007/s00531-011-0675-x

Araújo, T.M.F., 2004, Estudo da microfauna de foraminíferos do sedimento da superfície e da subsuperfície da plataforma e do talude continentais da região norte do estado da Bahia (Salvadora Barra do Itariri). PhD Thesis, UFBA, 525 p.

Bandopadhyay, P.C., 2007. Interpretation of authigenic vs. allogenic green peloids of ferric clay in the Proterozoic Penganga Group, southern India. Clay Minerals 42, 471-485. https://doi.org/10.1180/claymin.2007.042.4.06

Banerjee, S., Bansal, U., Thorat, A.V., 2016. Lithofacies palaeogeography and sedimentology. A review on palaeogeographic implications and temporal variation in glaucony composition. Journal of Palaeogeography 5(1), 41-71. DOI: http://dx.doi.org/10.1016/j.jop.2015.12.001

Banerjee, S., Chattoraj, S.L., Saraswati, P.K., Dasgupta, S., Sarkar, U., Bumby, A., 2012a. The origin and maturation of lagoonal glauconites: a case study from the Oligocene Maniyara Fort Formation, western Kutch, India. Geological Journal 47, 357 371. https://doi.org/10.1002/gj.1345

Banerjee, S., Chattoraj, S.L., Saraswati, P.K., Dasgupta, S., Sarkar, U., 2012b. Substrate control on formation and maturation of glauconites in the Middle Eocene Harudi Formation, western Kutch, India. Marine and Petroleum Geology 30, 144-160. https://doi.org/10. 1016/j.marpetgeo.2011.10.008

Banerjee, S., Jeevankumar, S., Eriksson, P.G., 2008. Mg-rich ferric illite in marine transgressive and highstand systems tracts: 
examples from the Paleoproterozoic Semri Group, central India. Precambrian Research 162, 212-226. https://doi.org/10.1016/j.precamres.2007.07.018

Banerjee, S., Mondal, S., Chakraborty, P.P., Meena, S.S., 2015. Distinctive compositional characteristics and evolutionary trend of Precambrian glaucony: example from Bhalukona Formation, Chhattisgarh basin, India. Precambrian Research 271, 33-48.

Berner, R.A., 1970. Sedimentary pyrite formation. American Journal of Science, 268, 1-23. https://doi. 10.2475/ajs.268.1.1

Berner, R.A., 1984. Sedimentary pyrite formation: An update. Geochimica et Cosmochimica Acta, 48 (4), 605-615. https://doi.org/10.1016/0016-7037(84)90089-9

Billo, S.M., 1987. Petrology and kinetics of gypsum-anhydrite transitions. Journal of Petroleum Geology 10, 73-85. https://doi.org/10.1111/j.1747-5457.1987.tb00997.x

Bornhold, B.D., Giresse, P., 1985. Glauconitic sediments on the continental shelf off Vancouver Island, British Columbia, Canada. Journal of Sedimentary Research 55 (5), 653-664. https://doi.org/10.1306/212F87AB-2B24-11D78648000102C1865D

Burk, C.A., Drake, C.L. (eds.), 1974. The Geology of Continental Margins. Springer-Verlag, 1009 p.

Burst, J.F., 1958. "Glaucony" pellets: their mineral nature and applications to stratigraphic interpretations. American Association of Petroleum Geologists Bulletin 42, 310-327.

Chattoraj, S.L., Banerjee, S., Saraswati, P.K., 2009. Glauconites from the Late Palaeocenee Early Eocene Naredi Formation, western Kutch and their genetic implications. Journal of Geological Society of India 73, 567-574. https://doi.org/10.1007/s12594-009-0040-x

Conley, R.F., Bundy, W.M., 1958. Mechanism of gypsification. Geochimica et Cosmochimica Acta 15, 57-72. https://doi.org/10.1016/0016-7037(58)90010-3

Curray, J.R., Dickinson, W.R., Dow, W.G., Emery, K. O., Seely, D. R., Vail, P.R., Yarborough, H., 1977. Geology of Continental Margins. Publisher: American Association of Petroleum Geologists. https://doi.org/10.1306/CE5387

Curray, J.R., 1965. Late Quaternary history, continental shelves of the United States. In: Wright and Frey eds., The Quaternary of the United States, Princeton, N.J., Princeton University Press, pp. 723-735.

Dasgupta, S., Chaudhuri, A.K., Fukuoka, M., 1990. Compositional characteristics of glauconitic alterations of K-feldspar from India and their implications. Journal of Sedimentary Petrology 60, 277-281. https://doi.org/10.1306/212F916F-2B24-11D78648000102C1865D

Davis, J. C., 1986. Statistics and data analysis in Geology. John Wiley and Sons, Inc., N. York. 646 p.

Deer, W.A., Howie, R.A., Zussman, J., 1992. An Introduction to the Rock-Forming Minerals Longman, London. 528 p.

Dominguez, J.M.L (coord.), Nunes, A.S., Silva, R.P., Esquivel, M.S., 2003. Diagnóstico oceanográfico e proposição de disciplinamento de usos da faixa marinha do litoral norte do Estado da Bahia. Salvador: Secretaria de Meio Ambiente e Recursos Hídricos do Estado da Bahia/CRA. 128 p.

Dominguez, J.M.L., Leão, Z.M.A.N., Lyrio, R.S., 1996. Roteiro da excursão E4 litoral norte do Estado da Bahia. In: Congresso Brasileiro de Geologia, Salvador.
Dyar, M.D., Gunter M.E., Tasa, D., 2008. Mineralogy and Optical Mineralogy. Mineralogical Society of America, Chantilly, Virginia. 708 p.

Ekau, W. and Knoppers, B., 1999. An introduction to the pelagic system of the North -East and East Brazilian shelf. Archive of Fishery and Marine Research 47 (2/3), 113-125.

El Albani, A., Fürsich, F.T., Colin, J.P., Meunier, A., Hochuli, P., Closas, C.M., Mazin, J.-M., Billon-Bruyat, J.-P., 2004. Palaeoenvironmental reconstruction of the basal Cretaceous vertebrate bearing beds in the northern part of the Aquitaine Basin (SW France): sedimentological and geochemical evidence. Facies 50, 195-215. https://doi.org/10.1007/s10347-004-0017-6

Finch, A.A., Allison, N. 2003. Strontium in coral aragonite: Sr coordination and the long-term stability of coral environmental records. Geochimica et Cosmochimica Acta 67, 4519-4527. https://doi.org/10.1016/S0016-7037(03)00410-1

Finch, A.A., Allison, N., Sutton, S.R., Newville, M., 2003. Strontium in coral aragonite: Characterisation of $\mathrm{Sr}$ coordination by EXAFS. Geochimica et Cosmochimica Acta 67, 1189-1194. https://doi.org/10.1016/S00167037(03)00410-1

Folk, R.R.L., Ward, W.W.C., 1957. Brazos River Bar: A study in the significance of grain size parameters. SEPM Journal of Sedimentary Research 27 (1), 3-26. https://doi.org /10.1306/74D70646-2B21-11D7-8648000102C1865D

Freire, A.F.M., 2006. A Seqüência Holocênica na Plataforma Continental Central do Estado da Bahia - Costa do Cacau. MsD Thesis, Universidade Federal da Bahia, Salvador, Brazil, $171 \mathrm{p}$.

Freitas, V.A., Ferreira, A.L., 2015. Bacia De Jacuípe. Agência Nacional do Petróleo, Gás Natural e Biocombustíveis Décima Terceira rodada de licitações. Superintendência de Definição de Blocos SDB., 13 p.

Gunatilaka, A., Al-Temeemi, A., Saleh A., Nassar, N., 1985. A new occurrence of basanite in recent evaporitic environments, Kuwait, Arabian Gulf. Journal of the University of Kuwait (Science) 12, 157-166.

Hardie, L.A., 1967. The gypsum-anhydrite equilibrium at one atmosphere pressure. American Mineralogist 52, 171-200.

Harris, L.C., Whiting, B.M., 2000. Sequence-stratigraphic significance of Miocene to Pliocene glauconite-rich layers, onand offshore of the US Mid-Atlantic Margin. Sedimentary Geology 134, 129-147. https://doi.org/10.1016/S00370738(00)00017-8

Hower, J., 1961. Some factors concerning the nature and origin of Glaucony. American Mineralogist 46, 313-334.

Jarosch, D., Heger, G.,1988. Neutron diffraction investigation of strontianite, $\mathrm{SrCO}_{3}$. Bulletin de Minéralogie111, 139-142.

Kang, N., Schmidt, M.W., Poli, S., Connolly, J.A.D., Franzolin, E., 2016. Melting relations in the system $\mathrm{FeCO}_{3}-\mathrm{MgCO}_{3}$ and thermodynamic modelling of $\mathrm{Fe}-\mathrm{Mg}$ carbonate melts. Contributions to Mineralogy and Petrology 171, 74. https://doi.org/10.1007/s00410-016-1283-3

Kholodov, V.N., Butuzova, G.Y., 2008. Siderite formation and evolution of sedimentary iron ore deposition in the Earth's history. Geology Ore Deposits 50, 299-319. https://doi.org/ 10.1134/S107570150804003X

Kinsman, D.J.J., Holland, H.D., 1969. The co-precipitation of cations with $\mathrm{CaCO} 3-\mathrm{IV}$. The co-precipitation of $\mathrm{Sr}^{2+}$ with 
aragonite between $16^{\circ}$ and $96^{\circ} \mathrm{C}$. Geochimica et Cosmochimica Acta 33, 1-17. https://doi.org/10.1016/0016-7037(69)90089-1

Kitamura, A., 1998. Glaucony and carbonate grains as indicators of the condensed section: Omma Formation, Japan. Sedimentary Geology 122, 151-163. https://doi.org/10.1016/S00370738(98)00103-1

Klein, C., 2005. Some Precambrian banded iron-formations (BIFs) from around the world: Their age, geologic setting, mineralogy, metamorphism, geochemistry, and origin. American Mineralogist 90, 1473-1499. https://doi.org/10.1016/00167037(69)90089-1

Krause, S., Liebetrau, V., Gorb, S., Sanchez-Roman, M., McKenzie, J. A., Treude, T., 2012. Microbial nucleation of Mg-rich dolomite in exopolymeric substances under anoxic modern seawater salinity: New insight into an old enigma. Geology 40 (7), 587-590. DOI:10.1130/G32923.1

Leão, Z.M.A.N., Brichta, A., 1996. Plataforma Continental. In: Barbosa, J.S.F., Dominguez, J.M.L. (eds), Geologia da Bahia: texto explicativo para o mapa geológico ao milionésimo. Salvador: Secretaria da Indústria, Comércio e Mineração. Superintendência de Geologia e Recursos Minerais, 400p.

Lee, C.H., Choi, S., Suh, M., 2002. High iron glaucony from the continental shelf of the Yellow Sea off the southwestern Korean Peninsula. Journal of Asian Earth Science 20, 507-515.

Lim, D., Park, Y., Choi, J., Cho, J.W., Khim, B.K., 2000. Glaucony grains in continental shelf sediments around the Korean Peninsula and their depositional implications. GeoMarine Letters 20, 80-86 https://doi.org/ $10.1007 / \mathrm{s} 003670000045$

Livramento, F.C. 2008. Padrões de Dispersão de Sedimentos ao Longo do Litoral Norte do Estado da Bahia: Subsídios para o Gerenciamento Costeiro. Trabalho Final de Graduação. Curso de Graduação em Geologia - Universidade Federal da Bahia, Salvador. 53 p.

Luther, G.W., 1991.Pyrite synthesis via polysulfide compounds. Geochimica et Cosmochimica Acta 55, 2839-2849. https://doi.org/10.1016/0016-7037(91)90449-F

Marone, E., Knoppers, B.A., Souza, W.F.L. Silveira, I.C., Godoi, S.S., 2010. The Brazil Current: Physical- Biogeochemical Domains. In: Liu, K.K., Atkinson, L., Quinones, R., TalaueMcmanus, L. (eds.), Carbon and Nutrients Fluxes in Continental Margins, Global Change - The IGBP Series, Springer, pp.153-169.

Martin, L., Bittencourt, A.C.S.P., Dominguez, J.M.L., 1999. Physical setting of the Discovery Coast: Porto Seguro region, Bahia. Ciência e Cultura 51, 245-61.

Martin, L., Flexor, J.L., Blitzkow, D. and Suguio, K., 1985. Geoid change indications along the Brazilian coast during the last 7000 years. $5^{\text {th }}$ International Coral Reef Congress, Tahiti 3, 85-90.

Martins, V., Abrantes, A., Grangeia, C, Paula, M., Nagai, R., Sousa, S.H.M., Laut, L.L.M., Dias, J.M.A., Dias, J.M., da Silva, E.F., Rocha, F., 2012. Records of sedimentary dynamics in the continental shelf and upper slope between Aveiro-Espinho $(\mathrm{N}$ Portugal). Journal of Marine Systems 96, 48-60. http://dx.doi: 10.1016/j.jmarsys.2012.02.001

Martins, V., Dubert, J., Jouanneau, J. M., Weber, O., da Silva, E. F., Patinha, C. Rocha, F., 2007. A multiproxy approach of the Holocene evolution of shelf-slope circulation on the NW Iberian Continental Shelf. Marine Geology 239 (1-2), 1-18. http://doi.org/10.1016/j.margeo.2006.11.001
Martins-Neto, M. A., 2006. Classificação de bacias sedimentares: uma revisão comentada. Revista Brasileira de Geociências 36 (1), 165-176.

McManus, D.A., 1975. Modern versus relict sediments on continental shelf. Geological Society of America Bulletin 86 (8), 1154-1160. https://doi.org/10.1130/0016-7606(1975) 86<1154:MVRSOT $>2.0 . \mathrm{CO} ; 2$

McRae, S.G., 1972. Glauconite. Earth-Science Reviews 8, 397440. Meiburg, E., Kneller, B., 2010. Turbidity Currents and Their Deposits. Annual Review of Fluid Mechanics 42,135-156. https://doi.org/10.1146/annurev-fluid-121108-145618

Melo, U., Summerhayes, C.P., Ellis, J.P., 1975. Salvador to Vitoria, Southeastern Brazil. In: Milliman, J.D., Summerhayes, C.P. (eds.), Upper continental margin sedimentation of Brazil. Contributions to Sedimentology 4, 8-116.

Milani, E.J., Rangel, H.D., Bueno, G.V., Stica, J.M., Winter, W.R., Caixeta, J.M., Pessoa Neto, O.C., 2007. Bacias sedimentares brasileiras: Cartas estratigráficas - Introdução. Boletim de Geociências da Petrobras, 15(2):183-198.

Milani, E.J., Brandão, J.A.S.L., Zalán, P.V., Gamboa, L.A.P., 2000. Petróleo na margem continental brasileira: geologia, exploração, resultados e perspectivas. Brazilian Journal of Geophysics 18 (3), 351- 396. http://dx.doi.org/ 10.1590/S0102-261X2000000300012

Millero, F.J., 2006. Chemical Oceanography 3rd edition [S.I.], CRC Press, 496p.

Mohriak, W.U., 2003. Bacias Sedimentares da Margem Continental Brasileira. In: Bizzi et al. Geologia, Tectônica e Recursos Minerais do Brasil: Texto, Mapas and SIG. Brasília: CPRM Serviço Geológico do Brasil, pp. 87-165.

Mohriak, W.U., Basseto, M., Vieira, S.I., 1998. Crustal architecture and tectonic evolution of the Sergipe-Alagoas and Jacuípe basins, offshore northeastern Brazil. Tectonophysics 288, 199220. https://doi.org/10.1016/S0040-1951(97)00294-1

Möller, H., Pistorius, P.C., 2007. The influence of $\mathrm{Sr}^{2+}$ on the formation of calcareous deposits on freely corroding low carbon steel in seawater. The Journal of the Southern African Institute of Mining and Metallurgy 107, 167-175.

Morris, R.V., Ruff, S.W., Gellert, R., Ming, D.W., Arvidson, R.E., Clark, B.C., Golden, D.C., Siebach, K., Klingelhofer, G., Schroder, C., Fleischer, I., Yen, A.S., Squyres, S.W., 2010. Identification of carbonate-rich out-crops on mars by the spirit rover. Science 329, 421-424. DOI: 10.1126/science.1189667

Netto, A.M., 2002. Morfologia e Sedimentologia da Plataforma Continental Entre os Rios Itariri e Itapicuru, Litoral Norte do Estado da Bahia. MsD thesis, Universidade Federal da Bahia, Brazil, $136 \mathrm{p}$.

Netto, A.S.T., Filho, J.R.W., Feijó, F.J., 1994. Bacias de Jacuípe, Camamú e Almada. Boletim de Geociências da PETROBRAS 8 (1),173-184.

Odin, G.S., Frölich, F., 1988. Glaucony from the Kerguelen Plateau. In: Odin, G.S. (Ed.), Green Marine Clays: Developments in Sedimentology, Elsevier, Amsterdam, pp. 277-294.

Odin, G.S., Fullagar, P.D., 1988. Geological significance of the glaucony facies. In: Odin, G.S. (ed.), Green Marine Clays: Developments in Sedimentology. Elsevier, Amsterdam. pp. 295-332. 
Odin, G.S. and Stephan, J.F., 1981. The occurrence of deep water glaucony from the eastern Pacific: the result of in situ genesis or subsidence? In: Watkins, J.S., Moore, J.C., et al. (Eds.), Init. Rep. DSDP 46, 419-428.

Odin, G.S., Matter, A., 1981. De glaucorianum originae. Sediment 28, 611-641.

Palache, C., Berman, H., Frondel, C.,1951. Dana's system of mineralogy, (7 ${ }^{\text {th }}$ edition), v. II, 196-200.

Prothero, D.R., Schwab F., 2004. Sedimentary Geology. An Introduction to Sedimentary Rocks and Stratigraphy. Freeman, New York. 500p.

Rickard, D.T., 1995. Kinetics of FeS precipitation: Part 1. Competing reaction mechanisms. Geochimica et Cosmochimica Acta 59, 4367-4379. https://doi.org/10.1016/0016-7037(95)00251-T

Rickard, D.T., 1997. Kinetics of pyrite formation by the H2S oxidation of iron (II) monosulfide in aqueous solutions between 25 and $125^{\circ} \mathrm{C}$ : the mechanism. Geochimica et Cosmochimica Acta 61, 135-147.

Rothwell, R.G., 1989. Minerals and mineraloids in marine sediments: an optical identification guide. Elsevier Applied Science, $279 \mathrm{p}$.

Runnegar, B., 1987. Shell microstructures of Cambrian molluscs replicated by phosphate. Alcheringa: an Australasian Journal of Palaeontology 9 (4), 245-257. http://dx.doi.org/ $10.1080 / 03115518508618971$

Schroeder, J.H., 1969. Experimental dissolution of calcium, magnesium and strontium from recent biogenic carbonates: a model of diagenesis. Journal of sedimentary Petrology 39, 1057-1073. https://doi.org/10.1306/74D71D98-2B21-11D78648000102C1865D

Shanmugam, G., 2013. Modern internal waves and internal tides along oceanic pycnoclines: Challenges and implications for ancient deep-marine baroclinic sands. AAPG Bulletin 97 (5), 799-843. https://doi.org/10.1306/10171212101

Siesser, W.G., Rogers, J.,1976. Authigenic pyrite and gypsum in South West African continental slope sediments. Sedimentology 23, 567-577. http://dx.doi.org/ 10.1111/j.1365-3091.1976.tb00068.x

Silva, E.N.S., 2008. A sedimentação na plataforma continental do Município de Conde (litoral norte da Bahia) desde o último máximo glacial: integração de dados sedimentológicos e geofísicos. Trabalho final de Graduação. Curso de Graduação em Geologia - Universidade Federal da Bahia, Salvador. 59 p.
Silveira, I.C.A., Schmidt, A.C.K., Campos, E.J.D., Godoi, S.S., Ikeda, Y., 2000. The Brazil current off the Eastern Brazilian Coast. Brazilian Journal of Oceanography 48 (2), 171-183. http://dx.doi.org/10.1590/S1413-77392000000200008

Soutelino, R.G., 2008. A origem da Corrente do Brasil. MsD Thesis, Universidade de São Paulo, Brazil, 120p.

Soutelino, R.G., da Silveira, I.C.A., Gangopadhyay, A., Miranda, J.A., 2011. Is the Brazil Current eddy-dominated to the north of $20^{\circ} \mathrm{S}$ ? Geophysical Research Letters 38, L03607, doi:10.1029/2010GL046276.

Soutelino, R.G., Gangopadhyay, A., da Silveira, I.C.A., 2013. The roles of vertical shear and topography on the eddy formation near the site of origin of the Brazil Current. Continental Shelf Research 70, 46-60. https://doi.org/10.1016/j.csr.2013.10.001.

Speer, J.A., Hensley-Dunn, M.L., 1976. Strontianite composition and physical properties. American Mineralogist 61, 1001-1004. Summerhayes, C.P., Coutinho, P.N., França, A.M.C., Ellis, J.P., 1975. Salvador to Fortaleza, Northeastern Brazil. In: Milliman, J.D. and Summerhayes, C.P. (eds). Upper continental margin sedimentation of Brazil, Contributions to sedimentology, Stuttgart. Schweizerbartsche Verlagsbuclrhandlung 4, 44-77.

Swift, D.J.P., Thorne, J.A.,1992. Sedimentation on Continental Margins. I. In Swift, D.J.P., Oertel, G.F, Tillman, R.W., Thorne, J.A. (eds.), A General Model for Shelf Sedimentation, in Shelf Sand and Sandstone Bodies: Geometry, Facies and Sequence Stratigraphy, Blackwell Publishing Ltd., Oxford, UK. DOI: 10.1002/9781444303933.ch1

Swift, D.J.P., Stanley, D.J., Curray, J.R., 1971. Relict Sediments on Continental Shelves: A Reconsideration. The Journal of Geology 79, (3), 322-46. http://www.jstor.org/ stable/30060194.

Ure, A., Berrow, M., 1982. Chapter 3. The elemental constituents of soils. In: Bowen, H.J.M. (Ed.), Environmental Chemistry. Royal Society of Chemistry, London. pp. 94-203.

Vieira, C.A., 2007. Sedimentação Holocênica na Plataforma Continental Entre Serra Grande e Olivença - Costa Central da Bahia (Costa do Cacau). Trabalho Final de Graduação. Curso de Graduação em Geologia - Universidade Federal da Bahia, Salvador. 46 p.

Wanderley Filho, J.R., Graddi, J.C.S.V., 1995. Estilos Estruturais da Bacia de Jacuípe - BA. In: Anais do V Simpósio Nacional de Estudos Tectônicos, Gramado-RS, pp. 325-326.

Warren, J., 2000. Dolomite: occurrence, evolution and economically important associations. Earth-Science Reviews 52 (1-3), 1-81. https://doi.org/10.1016/S0012-8252(00)00022-2

Zeller, E.J., Wray, J.L., 1956. Factors influencing precipitation of calcium carbonate. American Association of Petroleum Geologists 40 (1), 140-152. 